\title{
IN PURSUIT OF BETTER MYTH: \\ LAWYERS' HISTORIES AND HISTORIES OF LAWYERS
}

\author{
W. WESLEY PUE*
}

This article identifies the centrality of a presumed "history" of the profession in contemporary professional apologetics and rhetoric, illustrates the lack of support in empirical history for a number of contemporary "myths" and explores some implications of the disjunction between history and professional myth. Particular attention is paid to themes of self-regulation, independence of the profession and public service.
Le présent article reconnait la centralité d'une prétendue histoire de la profession située dans l'apologétique et la rhétorique; il illustre l'absence de fondement dans l'histoire empirique d'un certain nombre de "mythes» et explore les implications d'une disjonction entre l'histoire et le mythe professionnel. Une attention particulière est portée aux thèmes de l'auto-réglementation, de l'indépendance de la profession et du service public.

TABLE OF CONTENTS

I. INTRODUCTION .................. 731

II. THE IMPORTANCE OF PROFESSIONAL MYTH $\ldots \ldots \ldots 732$

III. CONTEMPORARY LAWYERS' MYTHOLOGIES $\ldots \ldots \ldots 733$

IV. A NOTE ON SOURCES OF

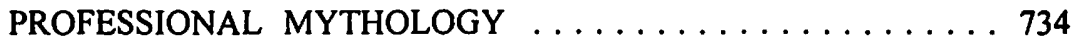

V. HISTORY AND MYTH IN CONTEMPORARY

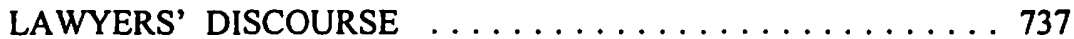

A. HISTORY "IN YOUR FACE" $\ldots \ldots \ldots \ldots \ldots \ldots \ldots 738$

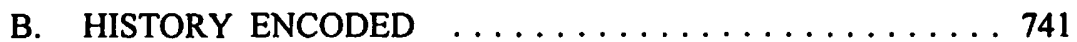

C. THE MYTH IN AGGREGATE $\ldots \ldots \ldots \ldots \ldots \ldots \ldots 747$

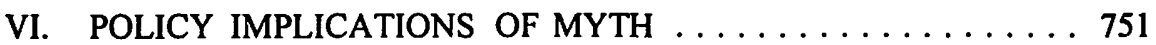

VII. PROFESSIONAL HISTORIANS' FALLACIES $\ldots \ldots \ldots \ldots \ldots 753$

VIII. HISTORIANS OF LAWYERS $\ldots \ldots \ldots \ldots \ldots \ldots \ldots \ldots 758$

IX. LAWYERS' HISTORIES: BRITISH,

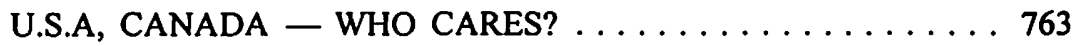

Nemetz Professor of Legal History, Faculty of Law, University of British Columbia. I would like to thank Professor Jonnette Watson Hamilton (Faculty of Law, University of Calgary) and Professor Susan Boyd (Professor of Feminist Legal Studies, University of British Columbia) for taking the time to read and comment on an earlier draft of this article. I am grateful to the Chief Executive Officers and staffs of law societies across Canada for providing me with the primary source material which this article draws upon. Professors M. Wylie, P. Rowbotham, A. Stalker, S. Martin, and J. Watson Hamilton put extraordinary effort into organizing the very useful "National Conference on the Legal Profession and Professional Ethics" for which this article was initially prepared. 


\section{INTRODUCTION}

What distinguishes the barrister from the insurance adjuster? The real estate conveyancer from the real estate agent?

Tradition!'

[A]ll invented traditions, so far as possible, use history as a legitimator of action and cement of group cohesion.... All historians, whatever else the objectives, are engaged in this process inasmuch as they contribute, consciously or not, to the creation, dismantling and restructuring of images of the past which belong not only to the world of specialist investigation but to the public sphere of man as a political being. ${ }^{2}$

Lawyers are history buffs, much enamoured with the traditions of their profession. Some may look to history for solace or for inspiration: the retreat to an objective and knowable past which speaks to the uncertainties of the present by providing proof incontrovertible that the entire cultural logic of our civilization mandates a particular form of professional organization, training or conduct. Others may look to history for critique, perhaps recalling the adage that those who forget history, who fail to heed its "lessons," are condemned to repeat it. ${ }^{3}$ There are also, no doubt, skeptics who wonder what possible contemporary relevance there can be in the actions or thoughts of long-dead lawyers.

This last position, I have to admit, is one to which I am drawn. Though I hope there is good reason to study history - and the histories of legal professions in particular it seems to me to be both naive and wildly optimistic to seek a singular moral "truth" in history. It is absurd to think that history repeats itself if only because, as every litigator and every expositor of legal doctrine knows all too well, no fact situation or problem ever repeats itself in exactly the same way as it appeared before. Even were this plausible, events can never recur because historical context itself changes. Nineteenth century London or New York is not the same place as late twentieth century Calgary or St. John's. Winnipeg in 1919 is not the same place as Edmonton in 1989. Edmonton in June 1995 is not the same as Edmonton in June 1994. The past - even the recent past - is always a foreign place. We can read travelogues but can never go there. We may remember but can never investigate first-hand. It is a foreign place that can never be known. Anyone who has booked a package holiday or returned to an old haunt knows this to be true. If you can never "go home," you most assuredly cannot fully know the past.

2 E. Hobsbawm, "Introduction: Inventing Traditions" in E. Hobsbawm \& T. Ranger, eds., The Invention of Tradition (Cambridge: Cambridge University Press, 1983) 1 at 13.

3 G. Santayana, The Life of Reason; Reason in Common Sense (New York: Charles Scribner's Sons, 1905) at 284: "Those who cannot remember the past are condemned to repeat it." 


\section{THE IMPORTANCE OF PROFESSIONAL MYTH}

History is not however irrelevant. The stories told about the past speak powerfully to the self-image of the story-teller. Collective stories define collective identities. Speaking about the past, we make ourselves for the present and project a future. The great Canadian cultural figure Northrop Frye explained,

We move in time with our backs to what's ahead and our faces to the past, and all we know is in a rear-view mirror....

The question "Where are we going?" assumes that we already know the answer to the question "Where are we now, and how did we get here?". We certainly don't know the answer to that one, and in fact all our really urgent, mysterious and frightening questions have to do with the burden of the past and the meaning of tradition. ${ }^{4}$

All of this would remain rather abstract and esoteric were it not the case that Canada's lawyers are, in fact, energetic purveyors of historical myth. The principle oracles of mythic knowledge are professional associations and mysterious communications from lawyers who have passed on to the glory of the judicial bench.

In speaking of professional "myths" it will, I hope, be understood that I am using that term in a quite precise way. I do not in the least intend to offend. The term carries no pejorative connotation and I certainly do not wish to be taken as implying anything at all resembling bad faith or a dissembling attitude on the part of professional apologists. Rather, I am content in understanding "mythology" as the active and communal process of "building worlds out of words."5 Lawyers, like novelists, journalists, poets, comedians or scholars, are word-spinners. As such, we are simultaneously liegeman to and Empress of the cultural uses and social functions of language. "Nobody," according to Frye, "can create, think or even act outside the mythology of his time, but a mythology is not some kind of prison; it is simply the whole body of material we work with. Like science, it is being recreated all the time, partly by critics and scholars and partly by literature itself, because every new writer recreates something already in literature."16

The task for lawyers cannot then be to transcend myth. It is futile to seek some objective "truth" beyond the bounds of place, time and culture - myth. We should however expect more rather than less thoughtful professional myth-making. Our most immediate goal should be to resist sanctifying our own unexamined assumptions. If we do not do this, we risk the wilful suppression of knowledge and descent into an abyss

$4 \quad$ N. Frye, "The Rear-View Mirror: Notes Toward a Future" in N. Frye, Divisions on a Ground: Essays on Canadian Culture (Toronto: Anansi, 1982) 181 at 183 (edited, with a preface, by James Polk).

s Ibid. at 185 .

6 Ibid. Dworkin's much celebrated account of how judges make law in common law systems shares much with Frye's account of literature. See R. Dworkin, Law's Empire (Cambridge: Harvard University Press, 1986). 
walled by "a complete and mostly phony mythology, made up of cliché and prejudice and stock response...."7

In pursuit of better myth this article will seek to explore, to tease-out, the mythic narratives which have underlain some important professional writings in Canada in recent years. By and large I have confined myself for these purposes to the publications of professional organizations. For the most part I have limited my review to common law jurisdictions out of respect for the variations in forms of professional organization and mythic foundations of professional culture which distinguish common law from civilian traditions in Canada. Even so limited, there is certainly room for a more comprehensive exploration of myth in Canadian lawyers' professional rhetoric. This project might have been - probably should have been - expanded so as to encompass sources such as judicial pronouncements, academic writings, Street Legal, jury addresses, newspaper articles, "talking head" television interviews, and so on. That too, however, is much beyond the ambit of this article. Much less do I hope to explore the deeper "mythologies of modern law" which may at a much more profound level ground European-derived legal systems in their entirety.

After identifying the major outlines of contemporary professional myth in Canada, I will critique the composite I have sketched. The point of reference in developing this critique will be the growing body of literature on the history of the legal profession which has been produced during the past two decades or so. My purpose is not to present "objective" historical fact against professional myth but only to illustrate the ways in which commonplace narratives are cluttered with unfounded prejudices, assumed histories, cliché, prejudice and stock-response. To appropriate Peter Fitzpatrick's language for purposes of my own, I seek here to subvert portions of received narratives "by heightening the contradictions and suppressions involved in their construction."

\section{CONTEMPORARY LAWYERS' MYTHOLOGIES}

Although anthropology and other human sciences abound with competing definitions of "myth," a number of components recur with some frequency:

(1) Myths are often stories dealing with "origins and identity, and in particular here with the origins and identity of a group or a people."

(2) Myth often provides "the basis for claiming ... a superiority for the group."

(3) "The point of origin is sacred - set apart, made transcendent and beyond encompassing in profane experience."

(4) "Such a self-generating, sacred force imposes and sustains an order from above. The ability to do this is often transferred in part to agents such as the first man made in the image of God." 
(5) Agents and forces mediate between the sacred and the profane. "Such mediations locate the profane, mortal world within the sacred, providing members of the group with guidance and orientation to a reality which is perceived and lived through myth."

(6) "Myth both sets the limits of the world, of what can be meant and done, and transcends these limits in its relation to the sacred."

(7) Contradictions and incoherencies might be obfuscated by "placing contradictory elements in distinct but related myths.... This is a relation of dependence of a myth on other myths for the revelation of its 'full' meaning. ${ }^{n 10}$

Most of these elements of "myth" recur with some frequency in Canadian professional apologetics." Professional apologetics is constructed within a web of interconnecting myths relating to self-regulation, independence of the profession, adversarial justice and public service.

\section{A NOTE ON SOURCES OF PROFESSIONAL MYTHOLOGY}

In seeking out contemporary accounts of professionalism I conducted a mail survey of lawyers' professional organizations across Canada. ${ }^{12}$ Each was approached with a request for information covering just about any sort of considered statement relating to the role of the legal profession in Canadian society. Specifically, I asked these organizations to provide me with copies of any documents such as "position papers, submissions to government commissions, public education pamphlets or such-like" speaking to any of the following sorts of matters:

- the social role of the legal profession,

- professional ethics,

- principles of self-regulation and/or the independence of the legal profession,

- the adversarial process,

- the public service orientation of a profession or the meaning of "professionalism"

and so on.

The sort of material that would be helpful to me relates to policy assessments, public statements or philosophical positions rather than the "hands-on" work that all professional organizations in Canada engage in with respect to the development of ethical codes or the application of rules in particular cases.

i11 Ibid. at 15-16.

11 So as to avoid causing offence I emphasize that I employ this term in a sense parallel to that in which one would speak of "Christian apologetics" - connoting "argumentative defence" or "justification" rather than "excuse."

12 The Law Society of Yukon; The Law Society of Northwest Territories; Federation of Law Societies of Canada; Law Society of British Columbia; The Law Society of Alberta; The Law Society of Saskatchewan; The Law Society of Manitoba; The Law Society of Upper Canada; Barreau du Québec; Chambre de Notaires du Québec; The Law Society of New Brunswick; Nova Scotia Barrister's Society; The Law Society of Prince Edward Island; The Law Society of Newfoundland; Canadian Bar Association. 
In all cases letters were addressed to the chief executive officer of the professional association as indicated in the 1994 British Columbia lawyer's telephone directory.

The responses have been varied. Four professional organizations responded with brief letters indicating that they have not prepared any such documents. ${ }^{13}$ The Nova Scotia Barristers' Society explained that, as "a small society, we tend to rely on the work of the larger jurisdictions to assist us in this area" ${ }^{14}$ but kindly provided me with a draft "objects clause" then under active consideration and with a copy of their new Legal Ethics Handbook. The Law Society of Saskatchewan sent me four publicity pamphlets $^{15}$ and I received an extremely interesting, very helpful thirty-five page document prepared by the Law Society of Newfoundland. ${ }^{16}$ The Law Society of British Columbia provided me with a copy of a paper prepared by its chief executive officer in 1993 and with a more recent "public briefing paper." 17 It has also been most helpful to me to be able to review the Submission of the Law Society of Manitoba in Response to the Law Reform Commission of Manitoba Discussion Paper on the Future of Occupational Regulation in Manitoba. ${ }^{18}$

I received an interesting package from the Law Society of Alberta - including the final report of their "Futures Committee,"19 an article by a former President of the Law Society of Alberta, ${ }^{20}$ and other material. ${ }^{21}$ I have on file copies of both an important government report and the law society's rather poorly constructed response - a

The Law Society of Yukon; The Law Society of Northwest Territories; The Law Society of New Brunswick; The Law Society of Prince Edward Island.

Letter of D.I. Pink to W.W. Pue (28 April 1994).

Law Society of Saskatchewan and Canadian Bar Association (Saskatchewan Branch), "The Self Governing Profession. An Introduction to the Functions and Responsibilities of The Law Society of Saskatchewan and the Canadian Bar Association" (pamphlet) [hereinafter "The Self Governing Profession"]; Law Society of Saskatchewan, "Lawyer Referral Service" (pamphlet); Law Society of Saskatchewan, "Seniors Legal Assistance Service" (pamphlet); Law Society of Saskatchewan, "Understanding your Lawyer's Fee" (pamphlet).

Law Society of Newfoundland, Brief to the Minister of Justice The Honourable Mr. Edward Roberts, Q.C. Submitted by: The Law Society of Newfoundland Re: Bill 55 - An Act to Amend the Law Society Act (May 1993) [hereinafter Brief to the Minister - Newfoundland].

B.R. Ralph, "Law Societies - Can they Meet the Need of the Public? A Canadian Point of View" (April 1993) [unpublished]; Law Society of British Columbia, Briefings: The Law Society of British Columbia (March 1994) [hereinafter Briefings].

Law Society of Manitoba, Submission of the Law Society of Manitoba in Response to the Law Reform Commission of Manitoba Discussion Paper on the Future of Occupational Regulation in Manitoba (March 1994) [hereinafter Manitoba Response].

Law Society of Alberta, Report of the Futures Committee (Calgary).

T.F. McMahon, "The Importance of Self-Governance" (1991) 6 Benchers' Advisory 1.

Law Society of Alberta, Proposed Code of Professional Conduct; Discussion Draft - November, 1992 (Edmonton: Law Society of Alberta, 1992); Law Society of Alberta, April 1994 Draft Proposed Code of Professional Conduct (Edmonton: Law Society of Alberta, 1994); Law Society of Alberta, Leaving the Practice of Law: A Survey of Non-Practising Members of the Law Society of Alberta (adapted from a report by Joan Brockman); Law Society of Alberta, Women and the Legal Profession in Alberta: Highlights of the Survey of Active Members; Law Society of Alberta "Lawyers of Alberta: Serving the Public Interest" (pamphlet); Law Society of Alberta "Reviewing the Conduct of Lawyers" (pamphlet). 
document which speaks powerfully to the ways in which professional rhetorics play in the world of myth. ${ }^{22}$

I am greatly indebted to the Barreau du Québec, ${ }^{23}$ the Chambre des notaires du Québec, ${ }^{24}$ the Law Society of Ontario ("Upper Canada") ${ }^{25}$ and the Federation of Law

Council on Professions and Occupations, Government of Alberta, Principles and Policies Governing Professional Legislation in Alberta (Edmonton: Queen's Printers, 1990) [hereinafter Professions and Occupations]; Law Society of Alberta (D. G. Bishop), Submission by the Law Society of Alberta to the Council on Professions and Occupations Regarding Discussion Paper: Principles and Policies Governing Professional Legislation in Alberta (January 1990) [hereinafter "Bishop Submission"].

P.E. Audet, "Il faut meriter la confiance du public" Journal du Barreau (15 October 1993) 8; Barreau du Québec, "Conciliation et arbitrage" (pamphlet) (Québec: Barreau du Québec, 1991); Barreau du Québec, "Fautes professionnelles d'avocats responsables" (pamphlet) (Québec: Barreau du Québec, 1993); Barreau du Quebec, La redéfinition des relations entre les peuples autochthones, l'ensemble des citoyens et le droit (Québec: Barreau du Quebec, 1993); Barreau du Québec, "Le mandat: une bonne idée... pas seulement pour les autres" (pamphlet) (Québec: Barreau du Quebec, 1993); Barreau du Québec, "Le Registre des testaments du barreau du Québec" (pamphlet) (Québec: Barreau du Quebec, 1991); Barreau du Québec, Les femmes dans la profession (Québec: Barreau du Quebec, 1992); Barreau du Québec, "L'Inspection Professionnelle, une affaire d'excellence!" (pamphlet) (Québec: Barreau du Quebec, 1993); Barreau du Québec, Mémoire sur le projet de règlement concernant la médiation familiale (Québec: Barreau du Quebec, 1993); Barreau du Québec, Mémoire sur les finances publiques du Québec (Québec: Barreau du Quebec, 1993); Barreau du Québec, Recueil de Documentation Professionnelle (Abridged English edition) Professional Code: An Act Respecting the Barreau du Québec Regulations (Québec: Societe québecoise d'information juridique, 1991); Barreau du Québec, "Vous et votre avocat" (pamphlet) (Québec: Barreau du Quebec, 1991); C. Bernard, "La representation des enfants par avocat" Journal du Barreau (15 February 1994) 11; P. Bernard, "Le devoir de confidentialite" Collection des habiletés C.F.P.B.Q. 1993-1994 (Montreal: Edition Ecole du Barreau du Quebec, 1993) 47; R. Blais, "Le Code de deontologie" Collection des habiletés C.F.P.B.Q. 1993-1994 (Montreal: Edition Ecole du Barreau du Québec, 1993) 14; D. Bois, "Une nouvelle culture juridique" Journal du Barreau (1 November 1992) 16; S. Borenstein, "Un mot de bienvenue" Journal du Barreau (15 November 1990) 6; P.P. Carriere, "L'autonomie des juges?" Journal du Barreau (15 February 1993) 6; P.P. Carriere, "Les attentes du public" Journal du Barreau (15 May 1993); P. Daignault, "Rentree judiciaire ... et non judiciaire" Journal du Barreau (15 October 1993)15; Code de déontologie des avocats, R.R.Q. 1982, c. B-1, r. 1 as am. by G.O.Q. 1993.II.2435; B. Landy, "Investments by Professional Partners with Firm Clients: A Legal Analysis of a Moral and Ethical Problem" (1989) 49 Rev. Barreau 433; D. Mockle, "Zero contentieux. L'ouverture d'une troisieme voie en droit administratif par le reglement amiable des differends" (1991) 51 Rev. Barreau 45; J. Paquet, "Pour en finir avec les maux!" Journal du Barreau (15 February 1992) 6; J. Paquet, "Une defi important a relever" Journal du Barreau (1 August 1991) 6; D. Paradis, "De la separation des pouvoirs" Journal du Barreau (15 October 1993) 6; D. Paradis, "Soyons imaginatifs! Soyons creatifs!" Journal du Barreau (1 August 1993) 6.

The Chambre des notaires was most generous in providing both photocopies of relevant information and a list of publications. Their fascinating material covered both "academic" and "professional" writings including: "L'independance personnelle et profesionnelle de l'avocat salarie" (1979) 39 Rev. du B. 744; J. Lambert, "L'independance du notaire" (Address to the Institut canadien d'administration de la justice, 16 October 1987) [unpublished]; J.-G. Belley, "La notion de protection du public dans la reforme du droit professionnel quebecois: une analyse socio-politique" (1980) 21 C. de D. 673; H.P. Glenn, "Professional Structures and Professional Ethics" (1990) 35 McGill L.J. 424; A.S. Manson, "Observations from an Ethical Perspective on Fitness, Insanity and Confidentiality" (1982) 27 McGill L.J. 196; G. Bourgeault, Ethique professionnelle: réalités du présent et perspectives d'avenir au Québec (Montreal: Fides, 1989); Institut canadien d'administration de la justice, Séminaire national sur la responsabilité 
Societies. ${ }^{26}$ Each of these inundated me with voluminous and very interesting documentation of all sorts.

\section{HISTORY AND MYTH IN CONTEMPORARY LAWYERS' DISCOURSE}

History is everywhere in contemporary professional apologetics. It appears both as in-your-face explicit appeals to "history" as a source of legitimacy for the contemporary

professionnelle (Octobre 1986); Ministére de la justice du Québec, Direction general des services judiciairies, l'ethique professionnelle envers... et contre tous (Montreal: Publications du Québec, 1981).

P. Aucoin, "Public Accountability in the Governing of Professions: A Report on the Self-Governing Professions of Accounting, Architecture, Engineering and Law in Ontario" (Professional Organizations Committee, Working Paper \# 4) (1978); Law Society of Upper Canada Archives, Crossing the bar: A Century of Women's Experience Upon the Rough and Troubled Seas of Legal Practice in Ontario/Dans leur droit: Un siècle d'histoire ou l'odyssee des avocates de I'Ontario (1993); Law Society of Upper Canada, Presentation to the Standing Committee on the Ombudsman (November 1992) [hereinafter Ombudsman]; Subcommittee on the Role of the Law Society, Proposed Role Statement (draft) (Toronto: Law Society of Upper Canada, November 1993); Law Society of Upper Canada, Submission to The Professional Organizations Committee by the Law Society of Upper Canada (Toronto: Law Society of Upper Canada, April 1979) [hereinafter Submission 10 Professional Organizations Committee]; Government of Ontario, Report of the Professional Organizations Committee (Ottawa: Queen's Printer, 1980) [hereinafter Report of the Professional Organizations Committee]; Royal Commission of Inquiry into Civil Rights, Report Number One, vol. 3 (Ottawa: Queen's Printer) [hereinafter McRuer Commission].

K. Campbell, "Independence of the Legal System in Canada: the Judiciary and the Legal Profession" (Address to the Federation of Law Societies of Canada/Fédération des professions juridiques du Canada, 21 August 1992) [unpublished]; B.W. Cotter, Professional Responsibility Instruction in Canada: A Coordinated Curriculum for Legal Education (Joint National Committee on Legal Education of the Federation of Law Societies of Canada/Fédération des professions juridiques du Canada and the Council of Canadian Law Deans, 1992) [unpublished]; Federation of Law Societies of Canada/Fédération des professions juridiques du Canada, Independence of the Legal System in Canada: The Media and the Legal System in Canada (Workshop Program, 20 August 1993) [unpublished]; Federation of Law Societies of Canada/Fédération des professions juridiques du Canada, The Independence of the Judiciary, the Profession and the Relations Between Them (Workshop Materials, 21 August 1992) [unpublished]; R.J. Matas \& D.J. McCawley, Legal Education in Canada: Reports and Background Papers of a National Conference on Legal Education held in Winnipeg, Manitoba, October 23-26, 1985 (Federation of Law Societies of Canada/Fédération des professions juridiques du Canada, 1987); R.J. Scott, "Independence of the Legal System in Canada: the Judiciary and the Legal Profession" (Address to the Federation of Law Societies of Canada/Fédération des professions juridiques du Canada, 21 August 1992) [unpublished] [hereinafter Scott Address]; J.M. Spence, "Independence of the Legal System in Canada: the Judiciary and the Legal Profession" (Address to the Federation of Law Societies of Canada/Fédération des professions juridiques du Canada, 21 August 1992) (hereinafter Spence Address]; L. Clarke, "Independence of the Legal System in Canada: the Judiciary and the Legal Profession" (Address to the Federation of Law Societies of Canada/Fédération des professions juridiques du Canada, 21 August 1992) [unpublished].

The Canadian Bar Association, in contrast, responded only with copies of three marginally relevant documents and a reference to two others. These were: "Mission Statement of the Canadian Bar Association" (adopted February 1992) [unpublished]; "Public Interest Intervention Policy" (Apri] 1991) [unpublished]; "Public Interest Intervention in Canadian Courts: A Background Paper to the Intervention Policy of the Canadian Bar Association" (March 1991) [unpublished]; Code of Professional Conduct (Toronto: Canadian Bar Association, 1988); and Alternative Dispute Resolution: A Canadian Perspective (Toronto: Canadian Bar Association, 1989). 
status quo and, much more subtly, through a series of cultural codings which are so well understood as to register subconsciously only. But register they do.

\section{A. HISTORY "IN YOUR FACE"}

Explicit appeals to "history" as a source of authority are found in law society publications from coast to coast. The Law Society of British Columbia, for example, recounts a number of historical tales in a public "briefing" document. It asserts that the contemporary structure of professional regulation in the province is "in keeping with the centuries-old tradition in England" and that "historically" the profession has been "given self-governing status because of society's belief that a lawyer cannot serve two masters."27 Lawyering, we are told, is "a profession," not a mere "trade" because "a profession has, over many years" developed an ethical code. ${ }^{28}$

The Alberta law society makes a similar appeal to history, claiming that despite its origins in an Alberta statute of 1907, the late twentieth century law society is a direct successor to mysterious "origins of an independent legal profession" which "can be traced to England in early times." Despite the long history of First Nations governance in the territory that is now Alberta, despite two centuries of nominal control by a private corporation, despite the origins of "western Canada" as a central Canadian colony, despite the fact that Alberta was only created in 1905, the Alberta legal profession is quite precise in asserting its origins far, far away and long, long ago: "Historically the profession developed as a self-governing entity before there was any legislation and although there has been a legislative framework in Alberta since 1907, it reflects that which had traditionally existed." One presumes here that the reference to what "traditionally existed" does not refer to Peigan or Cree professional structures. ${ }^{29}$ A dusty prairie town in 1907 cannot, one concludes, provide pedigree adequate to match the pretensions of the Alberta law society.

The Manitoba law society takes pride in the independence of the legal profession manifest in "a long history and tradition of self-governance" which is "rooted in the English common law." ${ }^{30}$ Saskatchewan modestly informs us only that "[h]istorically self government is rooted in the notion that a lawyer cannot serve two masters" and, therefore, that independence is "for the benefit of the client and the public, not the lawyers."131 More modestly still, the New Brunswick and Prince Edward Island legal professions have produced no internal studies or public documents whatsoever that speak to matters of professional organization, independence of the legal profession or

$27 \quad$ Briefings, supra note 17 at 1.

$28 \quad$ lbid. at 3 .

29 Bishop Submission, supra note 22 at 8-9. Following this astonishing historical assertion the document lapses into an entirely unintelligible discussion of differences between "self-regulatory" organizations and "delegated regulatory" organizations. 
self-governance. Despite a long, impressive and relatively well-researched history, ${ }^{32}$ the Nova Scotia Barristers' Society has produced only a draft "objects clause" emphasizing that the "regulatory role of the Society ... has a long history and a mandate that has evolved over the years." ${ }^{33}$ Newfoundland has produced an interesting document generally reiterating the argument that "lawyers have been viewed as standing between the government and private citizens" and, therefore, that lawyers must be "completely independent of government. ${ }^{134}$

Not the least modest or self-effacing, the Ontario law society has proved to be by far and away the most important producer of lawyer's histories in common law Canada. Several of its texts have entered into the Canadian canon of professional apologetics and a number of ideas first developed in Law Society of Upper Canada documents have popped up at various places in Canada with some frequency. In the November 1993 draft Proposed Role Statement, the Ontario law society invokes history frequently and powerfully. ${ }^{35}$ The date 1797 appears twice on page four, then on pages eight, ten, eleven (note twelve), and repeatedly in the three appendix pages where An Act for the better Regulating the Practice of the Law (U.K.), 37 Geo. III, c. 12 is "translated" into contemporary language and then reproduced in full (the translation itself is interesting, involving as it does the representation of a monarchical and committedly anti-democratic Imperial authority as the epitome of late twentieth century democratic constitutionalism). Overall three full pages of this seventeen page document are dedicated to a 1797 colonial statute, while that date appears five times over fourteen pages of the principle text - suggesting greater antiquity and a much higher degree of commitment to it than any other Canadian jurisdiction!

In its Presentation to the Standing Committee on the Ombudsman, the Ontario law society dedicates fully two pages to the "History and Responsibilities of the Law

See e.g. the works of Bell, Girard and Willis including: D.G. Bell, "Paths to the Law in the Maritimes, 1810-1825: The Bliss Brothers and their Circle" (1988) 8 N.S. Hist. Rev. 6 [hereinafter "Bliss Brothers"]; D.G. Bell, "Religious Liberty and Protestant Dissent in Loyalist New Brunswick" (1987) 36 U.N.B.L.J. 146; D.G. Bell, "Slavery and the Judges of Loyalist New Brunswick" (1982) 31 U.N.B.L.J. 9 [hereinafter "Slavery"]; D.G. Bell, "Richard John Uniacke's Advice to a Young Lawyer, 1797" (1988) 8 N.S. Hist. Rev. 136 [hereinafter "Uniacke"]; D.G. Bell, "Judicial Crisis in Post-Confederation New Brunswick" in D. Gibson \& W.W. Pue, eds., Glimpses of Canadian Legal History (Winnipeg: Legal Research Institute, University of Manitoba, 1991) [hereinafter "Judicial Crisis"] and [hereinafter Glimpses]; D.G. Bell, "The Transformation of the New Brunswick Bar 1785-1830: From Family Connexion to Peer Control" in Papers Presented at the 1987 Canadian Law in History Conference, vol. 1 (Ottawa: Carleton University, 1987) 240 [hereinafter "Transformation"]; P. Girard, "His whole life was one of continual warfare': John Thomas Bulmer, Lawyer, Librarian and Social Reformer" (1990) Dahousie L.J. 376 [hereinafter "Bulmer"]; P. Girard, "The Roots of a Professional Renaissance: Lawyers in Nova Scotia, 1850-1910" in Gibson \& Pue, eds., Glimpses, ibid. [hereinafter "Renaissance"]; P. Girard, "The Maritime Provinces, 1850-1939" in Canadian Legal History Project Working Papers, 1992-9 [hereinafter "Maritime"]; J. Willis, A History of Dalhousie Law School (Toronto: University of Toronto Press, 1979). 
Society." ${ }^{36}$ "History" makes frequent re-appearances thereafter. ${ }^{37}$ An earlier document, the Ontario law society's Submission to The Professional Organizations Committee, is also replete with historical observations some of which, in turn, have entered the professional canon. This document informs us that "law" reflects the "community" but is "essentially conservative," ${ }^{38}$ and that lawyers have an important and unique historical function (the "protection of rights"). ${ }^{39}$ It makes a powerful claim to ancient English tradition, fusing the colonial professional association with "its origins in England" and arguing that this history serves to "demonstrate the close association between the administration of justice and, not only lawyers, but their governing bodies as well." "This association," it is said, "has continued for centuries." ${ }^{40}$ A collection of huts on a swampy colonial shore cannot, it seems, provide pedigree adequate to match the pretensions of the Law Society of Upper Canada.

A substantial portion of the first chapter of this report, headed "The Independence of the Legal Profession," addresses the history of the profession." In addition to the above-cited remarks, this includes citation of Holdsworth on 250 years of (English) professional history, ${ }^{42}$ an argument that the law society is not a "public" body despite its creation by statute ${ }^{43}$ and a genuinely astonishing argument for continuity of institutional order from the 1300 s through 1797 to the present. ${ }^{44}$ Again fusing the histories of an Imperial and a colonial legal profession, this portion of the report concludes that

[t]his historical review has established that the Bar in England and in Ontario grew independently of government and exercises responsibility of its own making; that it requested and obtained from government recognition and a legal framework within which it continues to discharge its functions; that this independence of the Bar is necessary to the independence of the Bench and to the freedom for the individual citizens.... Unless there is strong reason for change a structure which has evolved over centuries and which is working well should not be interfered with. ${ }^{45}$

One intelligent and carefully balanced address by a Treasurer of the Law Society of Upper Canada is also replete with historical reference, including several pages on "the origins of the modern legal profession in the European Renaissance," 46 an invocation of the antiquity of lawyers' governing bodies in Canada - "The history of the

Ombudsman, supra note 25 at 2-3.

Ibid. at 8-9.

Submission to Professional Organizations Committee, supra note 25 at 1-2.

Ibid. at 3; (subsequently cited in Ombudsman and Proposed Role Statement, supra note 25; and paraphrased without attribution in "Bishop Submission," supra note 22).

Submission to Professional Organizations Committee, ibid. at 3; (subsequently cited in Ombudsman, supra note 25 at 12).

Submission to Professional Organizations Committee, ibid. at 3-8.

Ibid. at 3.

lbid. at $4-5$.

lbid. at 5 .

Ibid. at 7-8. It is noteworthy that the history of "the bar" is here misadapted to apply to a contemporary profession composed largely of individuals doing work of sorts not traditionally associated with the barrister's profession.

Spence Address, supra note 26 at 2-5. 
governing bodies in Canada is a long one, stretching back two hundred years...," ${ }^{47}-$ and an appeal to the Canadian "tradition" of relying on "the self-governing status of the legal profession" to ensure "the independence of lawyers." ${ }^{48}$

In summary, then, it is not hard to find explicit appeals to "history" in the writings of Canadian law societies and their officers. I expect that a more thorough survey of professional literature in general would reveal a deep substrata of historical references. The point here is not to analyze or assess the content of these historical arguments but simply to note the frequency with which they appear. One suspects that there would be much less frequent appeals to either ancient English history or to the continuity of Canadian tradition in other professions such as nursing, teaching, engineering or dental hygiene. The professional organizations of physicians, surgeons, psychiatrists and psychologists are, of course, generally content to overlook the quack theories and brutal bodily assaults which have constituted their "respectable practice" in times past! Law alone celebrates, relishes and revels in a vision of the past.

The past which lawyers celebrate, however, is richer, more subtle and more pervasive than even this brief account of in-your-face professional histories would suggest. There is also a history "encoded" in professional rhetoric which contributes powerfully to our myths.

\section{B. HISTORY ENCODED}

Every litigator, historian, literary critic and legal historian knows well that language does not work in a simple, straight-forward or linear way. "[L]anguage is not," according to Mariana Valverde, "a transparent window giving access to the world but is rather itself a part of the world, a kind of object among objects...." ${ }^{49}$ Words can communicate meaning more or less directly ("literally") or by complex interplays of images, associations or histories. Sometimes, perhaps invariably, the most simple statement communicates both sorts of meanings simultaneously.

Cultural context loads words with "slippages" whereby text apparently directed to one purpose simultaneously conveys meanings of quite another sort. ${ }^{50}$ In all cultures — including our own - "certain images, words, or constellations or both [resonate] ... with pre-existing cosmologies...." $\mathrm{Sl}$ Meaning is carried through multiple series of representations in which there is no "one-to-one correspondence of signifier and signified" but rather socially shared attributions of meaning working by means of "complex metaphors and chains of metonymies" - "complex relationships within each allegory and among different allegories/ symbols...."52 Full understanding cannot be had at the surface level. "The meaning of texts is not contained within their boundaries;

lbid. at 7 (the same point is made in different words, ibid. at 5). 
it can only be deciphered - and the power relations constituted by it exposed through a thorough knowledge of the social context in which the texts were produced. ${ }^{\text {"53 }}$

Obvious and simple though it is, this insight has produced powerful new approaches to the understanding of English literature, ${ }^{54}$ history, ${ }^{55}$ contemporary culture, ${ }^{56}$ geography ${ }^{57}$ and law. ${ }^{58}$ Because, on this approach, understandings of text depend upon the reader's or audience's appreciation as well as the intent of an author or speaker, "real" meaning is elusive. Contextual understanding must however be sought. There is no meaning more "real."

It is through such an appreciation of the ways in which language works that "encoded" histories can be identified throughout the literature of "professional apologetics." References to "liberty," personal freedom, or the "rule of law" infiltrate professional apologetics at every turn, producing linguistic slippages which lead the reader to quite wide-ranging associations - all of them, not surprisingly, tending towards reinforcement of the professional status quo. To illustrate the ways in which these slippages work, it may be helpful to consider some sample quotations, followed by an account of the sorts of historical readings which are likely to be brought to these texts. First, the examples:

It may be trite to say that a free and independent legal system is a fundamental right in a free and democratic state. The dual components of any legal system are an independent judiciary and an independent bar. Without both, a legal system is not free, but is merely an agency designed to do the will of the state. 9

It is to an independent legal profession that a citizen must look to address his or her grievances against the state or to protect his or her interests from excessive, unlawful or improper interference by the

Ibid. at 43. For a recent defence and application of the hermeneutic tradition in another context, see S. Cornell, "Moving Beyond the Canon of Traditional Constitutional History: Anti-Federalists, the Bill of Rights, and the Promise of Post-Modern Historiography" (1994) 12 L. \& Hist. Rev. 1. E.g. E.W. Said, Orientalism (New York: Vintage, 1978).

E.g. Valverde, supra note 49.

L. Grossberg, C. Nelson \& P. Treichler, eds., Cultural Studies (New York: Routledge, 1992); S. During, ed., The Cultural Studies Reader (London: Routledge, 1993). A model study of the interaction of text, image and audience is found in J. D'Acci, Defining Women: Television and the Case of Cagney \& Lacey (Charlotte: University of North Carolina Press, 1994), especially in c. 5, "Female/Feminine/Feminist Audiences, Spectators, and Readings" at 168-203.

R. Shields, Places on the Margin: Alternative Geographies of Modernity (London: Routledge, 1991). See also N.K. Blomley, Law, Space, and the Geographies of Power (New York: The Guildford Press, 1994).

See e.g. H.L.A. Hart, The Concept of Law (Oxford: Clarendon Press, 1961); P. Fitzpatrick, "The Abstracts and Brief Chronicles of the Time: Supplementing Jurisprudence" in P. Fitzpatrick, ed., Dangerous Supplements: Resistance and Renewal in Jurisprudence (London: Pluto Press, 1991) 1; M.J. Frug, Postmodern Legal Feminism (London: Routledge; 1992); P. Fitzpatrick, The Mythology of Modern Law (London: Routledge, 1992).

"Bishop Submission," supra note 22 at 2 (this passage appears almost verbatim in "The Importance of Self-Governance," supra note 20 at 1-2). 
state. Therefore it is surely a fundamental public right to have access to a truly independent bar for those purposes. ${ }^{60}$

The legal profession has a unique position in the community. The distinguishing feature is that alone among the professions it is concerned with protecting the personal and property rights of citizens from whatever quarter they may be threatened and pre-eminently against the threat of encroachment by the state. The protection of rights has been an historic function of the law and it is the responsibility of lawyers to carry out that function. ${ }^{\text {. }}$

Stress was rightly laid on the high value that free societies have placed historically on an independent judiciary, free of political influence on its decisions, and an independent bar, free to represent citizens without fear or favour in the protection of individual rights and civil liberties against incursion from any source, including the state. ${ }^{62}$

The necessity of the independence of the judiciary is well recognized. The significance of the independence of the profession is often not fully understood. The profession is the source and training ground of the judiciary. ${ }^{03}$

This historical review has established that ... independence of the Bar is necessary to the independence of the Bench and to the freedom for the individual citizens.... Unless there is strong reason for change a structure which has evolved over centuries and which is working well should not be interfered with. ${ }^{64}$

Since in a free and democratic society the legal profession stands between the government and the individual, it is important that the governing body of the legal profession remain totally independent of govemment. ${ }^{\text {ss }}$

It is recognized that an independent legal profession is essential to a democratic society. The Chief Justice of the Trial Division of the Supreme Court of Newfoundland, in addressing newly admitted members of the Bar has stated that:

"Officers of the Court assume a very solemn obligation to defend the independence of the judiciary at all times and when appearing as barristers, to follow the standard of ethical conduct which prevails amongst practising lawyers in this Province. Hand in

"Bishop Submission," ibid. at 2-3 (this passage, too, appears almost verbatim in "The Importance of Self-Governance," ibid.).

61 Submission to Professional Organizations Committee, supra note 25 at 3 (cited in Proposed Role Statement, supra note 25 and Ombudsman, supra note 25 at 11 and substantially reproduced without attribution in "Bishop Submission," ibid. at 5, and again without attribution, in "The Importance of Self-Governance," ibid. at 1-2. These texts all closely follow words found in McRuer Commission, supra note 25.

62 Report of the Professional Organizations Committee, supra note 25 at 26 (cited by lacobucci J., in Pearlman v. Manitoba Law Society Judicial Committee (1991), 84 D.L.R. (4th) at 118-19 [hereinafter Pearlman]); Brief to the Minister - Newfoundland, supra note 16 at 8, cited in Proposed Role Statement, ibid. at 4 and Ombudsman, ibid. at 13.

63 Submission to Professional Organizations Committee, supra note 25 at 3 (also cited in Ombudsman, ibid. at 12). 
glove with the independence of the judiciary goes the independence of the Bar. It therefore follows that the constitutional protection which guarantees the independence of the judiciary applies with equal certainty to the independence of the legal profession."

Lawyers have been viewed as standing between the government and private citizens who are directly impacted by the laws and regulations of government. Unless lawyers are completely independent of government, they cannot objectively interpret the laws and represent citizens in their interactions or conflicts with the laws and the government. ${ }^{66}$

The legal profession has historically been given self-governing status because of society's belief that a lawyer cannot serve two masters. A lawyer who represents a client must have one allegiance and only one: the client's best interests. A lawyer who is accountable to government for his or her actions would inevitably let that relationship colour the handling of the client's affairs. It is a hopeless case of conflicting interests, and the loser is the client ... graphic examples from totalitarian countries.... Our legal system has always guaranteed the independence of the legal profession, not for the benefit of lawyers, but for the benefit of their clients ... the importance of the rule of law in a free and democratic society. ${ }^{67}$

Such passages will, of course, be understood in many different ways by different types of readers. Let us assume however that they are directed to a reader from the common law provinces of Canada who has had some direct or indirect exposure to British constitutional history as that subject was popularly understood in early to mid-twentieth century Anglo-Canada (I am thinking of individuals whose primary exposure to history would be through potted high school versions or their equivalent) and who is complacent about or reasonably content with the current state of social, political and economic affairs in Canada - someone, in other words, very like Anglo-Canada's political and legal elite: white, Anglo-Saxon, Protestant or agnostic, middle-aged, middle-class and, perhaps, male. The interpretive "grid" which overlays everything such a person reads involves a number of assumptions or working hypotheses about the way the world works and about what history has to say about human society.

His or her "pop" sociology and history might well be founded in the belief that there is no value greater than that of individual liberty (which might be valued either as a moral end in itself or because individual liberty is thought to promote economic, scientific or moral advance). Happily, our hypothesized reader has concluded that no country is more "free" (or, at least, not substantially more free) than Canada. We are fortunate to have attained, through a lengthy historical process of evolution, a unique combination of liberty and political stability. Canadians, our reader concludes, are heirs to a peculiarly British tradition of liberties which can be traced back at least as far as the Magna Carta. Over the centuries, an evolving British constitutionalism has seen the displacement of monarchical power by "democracy." This has happened, our reader thinks, without descent into the "lawlessness" that so many other countries have experienced when "mobs" have taken control through violent revolution (looking 
askance at this point across the English Channel and recalling with horror 1789). The "magic key," the "genius of the English people" is found in the peculiarly British notion of the "rule of law" which has developed over centuries to protect us from the pretensions of monarchs and the excesses of mobs alike. Under the "rule of law," the courts have been crucially important forums for the protection of liberties. In order for them to be able to do this, it has been of the utmost constitutional importance that English practice has established both the independence of the judiciary from the legislative and executive branches of government and the independence of the legal profession. In the result, Canadians are heirs and successors to a series of privileges and freedoms which together constitute the much celebrated "Englishman's birthright." These include security of property,

freedom from foreign domination.... Freedom from absolutism (the constitutional monarchy), freedom from arbitrary arrest, trial by jury, equality before the law, the freedom of the home from arbitrary entrance and search, some limited liberty of thought, of speech, and of conscience, the vicarious participation in liberty ... afforded by the right of a parliamentary opposition and by elections ... as well as freedom to travel, trade, and sell one's own labour....

Taken together, "the rule of law was the distinguishing inheritance of the "freeborn Englishman', and was his defence against arbitrary power...." ${ }^{169}$ The bloodless and "Glorious Revolution" of 1688 has an important place in this cultural tradition not as a bold embrace of the future but as a restoration of ancient rights. ${ }^{70}$

If anything even vaguely resembling this sort of historic consciousness can be presumed on the part of the readership of Canadian professional apologetics, it is

E.P. Thompson, The Making of the English Working Class (Harmondsworth, England: Penguin, 1968) at 86.

Ibid. at 90. The "rule of law" should not here be understood as in any way equivalent to the post-Dicey understanding which infuses Canadian legal discourse. For further probing of the meanings of "rule of law," see E.P. Thompson, Whigs and Hunters: The Origin of the Black Act (New York: Pantheon Books, 1975); E.P. Thompson, Customs in Common: Studies in Traditional Popular Culture (New York: New Press, 1993); G.B. Baker, "'So Elegant a Web': Providential Order and the Rule of Secular Law in Early Nineteenth Century Upper Canada" (1988) 38 U.T.L.J. 184 [hereinafter "Elegant Web"]; G.B. Baker, "The Juvenile Advocate Society, 1821-1826: Self-Proclaimed Schoolroom for Upper Canada's Goveming Class" in Canadian Historical Association, Historical Papers (Ottawa: Canadian Historical Association, 1986) 74 [hereinafter "Juvenile Advocate"]; P. Romney, Book Review of D.O. Carrigan, Crime and Punishment in Canada - A History (1993) 8 Can. J.L. \& Soc.; P. Romney, "From Constitutionalism to Legalism: Trial by Jury, Responsible Government, and the Rule of Law in the Canadian Political Culture" (1989) 7 L. \& Hist. Rev. 121 [hereinafter "Trial by Jury"]; P. Romney, "From the Rule of Law to Responsible Government: Ontario Political Culture and the Origins of Canadian Statism" in Canadian Historical Association, Historical Papers, ibid. at 86 [hereinafter "Canadian Statism"]; P. Romney, "From the Types Riot to the Rebellion: Elite Ideology, Anti-legal Sentiment, Political Violence, and the Rule of Law in Upper Canada" (1987) 79 Ont. Hist. 113 [hereinafter "Types Riot"]; P. Romney, "Very Late Loyalist Fantasies: Nostalgic Tory History and the Rule of Law in Upper Canada" in W.W. Pue \& B. Wright, eds., Canadian Perspectives on Law and Society: Issues in Legal History (Ottawa: Carleton University Press, 1988) 119 [hereinafter "Fantasies"]. Supra note 68 at 94; see also G. Marquis, "In Defence of Liberty: 17th Century England and 19th Century Maritime Political Culture" (1993) 42 U.N.B.L.J. 69. 
apparent that an encoded history is all-pervasive in the informational pamphlets, informal statements and considered arguments produced by lawyers' organizations in Canada. While the "British liberties" theme occasionally touches down with concrete historical reference (to Magna Carta or to 1688), for the most part encoded histories register in popular consciousness only through knowledge that the heirs to British constitutionalism are the most free peoples in the world. The repeated references to England take on a heightened poignancy here. British tradition is invoked not merely as the imperial source of our institutions but also because England constitutes a conceptual apex of liberties - a sort of end-point of history: more free, more stable, more developed, more pristine than any other human society at any other time or place (except, perhaps, us now). The tradition invoked is white, not red; occidental, not oriental; free, not absolutist; European, not African; and, importantly, English, not French!

In celebration of British achievement, multiple "others" are constructed as unenlightened, illogical, inferior or simply dangerous. "British liberties" always invokes in the reader memories of a dangerous counter-example; the reader however being left to fill in the blank on his or her own, as it were. The genius of Alfred Hitchcock and professional apologists alike lies in consistently acting upon the knowledge that an audience can be more effectively terrorized by suggestion than by graphic, detailed, hysterical portrayal. Thus, for example, simple and seemingly straightforward assertions to the effect that without an "independent bar" the entire legal system is transformed into an instrument of the state ${ }^{71}$ does not merely communicate a political belief but also conjures up ghosts of oppressive states throughout history. Depending on the reader, the image which moves to the foreground may be that of Stalin, Castro, Hitler, Mussolini, Idi Amin, the Pope, George III, Louis XIV, General Cedras, Napoleon, Chairman Mao, Richard Nixon, the generals of Latin America, Ollie North or Charles II. $^{72}$ All of these - and many more - lurk in the background for our supposed reader. Rather than appearing as weakness, the imprecision of encoded historical reference is a source of great power: presumed alternative histories are called to mind instantly and in infinite variation. Like Orwell's terrifying "room 101," professional myth intimidates through confident knowledge that "[t]he worst thing in the world varies from individual to individual." 73 "But for" an independent bar, Canada might not have escaped any number of unnamed horrors of despotism and revolution.

The implication that the present set of institutional arrangements in Canada is both the logical endpoint of developments within a long tradition of "British liberties" and that this tradition is better than any developed by lesser peoples, including those south

7 "Bishop Submission," supra note 22 at 2.

72 A British Baptist's view on Charles II is provided in R.E. Cooper, From Stepney to St. Giles': The Story of Regent's Park College, 1810-1960 (London: Carey Kingsgate Press, 1960) at 11: "What happened became known as the Restoration. It was a restoration indeed; the restoration of a capricious monarchy, albeit at the invitation of Parliament, and a spirit of intolerance which put the clock back to the days of Charles I and Archbishop Laud. What his father lacked in wisdom, the new king supplied in cunning." 
of the forty-ninth parallel, ${ }^{74}$ is irresistible. Many of the statements reproduced above encode historical narratives of just this sort and several of these have entered into the emergent canon of professional utterances on these matters. ${ }^{75}$ Inferentially, of course, critics of the status quo have either chosen to side with Stalin, Hitler and Charles II or are simply too uninformed to know any better.

While at least two law societies have explicitly raised the spectre of "graphic examples from totalitarian countries"76 it is, on the whole, unnecessary to do so. Simply reminding the reader that Canada is a "free and democratic society" and that the legal profession in this country is organized in a certain way is sufficient to call forth a whole range of such associations. When some, such as Mr. Justice Estey, imply that a free legal profession is the principle bulwark protecting us from unspeakable horrors ("in a free society ... [there is] no area more sensitive than the independence ... of the members of the bar" ${ }^{\prime \prime 7}$ ) they render explicit only a portion of the meanings found in "history encoded."

\section{THE MYTH IN AGGREGATE}

It is, I hope, apparent from the above that "histories" of both the "in-your-face" and "encoded" varieties pervade professional apologetics in Canada. A very large portion of such literature is dedicated to one form or another of historical assertion rather than contemporary policy argumentation. Indeed, it could be said with very little fear of contradiction that such "policy" arguments as appear in these writings are so coloured by encoded histories as to amount to little more than historical myth in disguise.

Many features of the generalized historical "myth" as it appears in common law Canada will be apparent from the passages which have been quoted or described above. A sort of aggregate myth emerges which can be compared with what historians of the legal profession have been finding in Canada and elsewhere. In summary, the historical portrait Canadian legal professions draw of themselves looks something like this:

75 "Bishop Submission," supra note 22 at 2-3, 5; Report of Professional Organizations Committee, supra note 25 at 3, 7-8; Brief to the Minister - Newfoundland, supra note 16 at 3; Briefings, supra note 17 at 1.

76 Briefings, ibid. at 1 . See the more subtle development of this theme by citation of international Human Rights work focusing on lawyers in Brief to the Minister - Newfoundland, ibid. at 9-10; see also B.F. Ralph, "Law Societies - Can they Meet the Need of the Public? A Canadian Point of View" (1993) at 12.13 [unpublished], explaining the need to educate the public as to "the importance of the independence of the legal profession" in light of "dramatic and tragic incidents" reported in Centre for the Independence of Judges and Lawyers of the International Commission of Jurists, Attacks on Justice (Geneva: International Commission of Jurists, 1992). British Columbia (A.-G.) v. Law Society of British Columbia, [1982] 2 S.C.R. 307 at 336 [hereinafter A.-G. v. L.S.B.C.].

78

A further development of these ideas would require an assessment of British views of the superiority of their structures by comparison with those across the Channel (particularly in France) or across the Atlantic in the revolutionary colonies and, inferentially, of Anglo-Canadian perceptions of Quebec. The ideas canvassed by R. Young, White Mythologies: Writing History and the West (London: Routledge, 1990), might well prove to be invaluable in accessing the embedded histories in professional apologetics as in other sorts of literature. 
(1) a centuries-old English tradition requires that lawyers be governed by a body of other lawyers organized, as it happens, much in the fashion of any Canadian law society. ${ }^{79}$ In this respect Canadian lawyers are heirs to the amalgamated traditions of all English legal professions. In particular, we are heirs to the combined traditions of the English bar and the solicitors' profession, there being no distinction of importance between these two traditions.

(2) Despite the existence of statutes which appear to have created the possibility of self-governing legal professions (1885 or 1907 in Alberta; 1797 or 1822 in Ontario), the true origins of independent legal professions in Alberta and Ontario are to be found in private institutions in England in early times. There is a direct (though unexplained) continuity from ancient English institutions which were not created by the state through to modern Canadian law societies. ${ }^{80}$

(3) The contemporary law society in British Columbia dates from 1884 and has since then enjoyed "full authority over lawyers and the practice of law in the

Briefings, supra note 17 at 1; Submission to Professional Organizations Committee, supra note 25 at 5-7.

so "Bishop Submission," supra note 22 at 8-9; Submission to Professional Organizations Committee, ibid. at 3 (also cited in Ombudsman, supra note 25 at 12); Submission to Professional Organizations Committee, ibid. at 5-6. James Spence partially defers to this position in asserting that "our governing bodies ... are recognized or created by statute...." (Spence Address, supra note 26 at 8 ).

A more developed, scholarly, and nuanced assessment ultimately falls into this category: D.T. Anderson, "The Legal Profession and the Public Interest" in C. Harvey, ed., The Law Society of Manitoba, 1877-1977 (Winnipeg: Peguis Publishers, 1977) 1. Professor Anderson argues against any form of government regulation of the profession, stressing continuity of professional form from the ancient English Inns to the modern Manitoba legal profession (ibid. at 2-3); he argues in favour of monopoly of the legal profession to remedy alleged market failures (ibid. at 19); and he asserts that the liberties of subjects depend on a self-regulating legal profession (ibid. at 16-17, 20-21). The tenor of Professor Anderson's argument is captured in the following passage:

It is often asserted or implied that a profession is the creation of the state and all of its powers and privileges are delegated to it by the state. It will be suggested below that while this may ultimately be true ... in the case of the legal profession at least this is a gross over-simplification, misleading in its tendency, of an historical evolution in which a complex relationship has been maintained between the profession, the courts, and the executive arms of the state. (ibid. at 10).

In Ontario, at any rate, the courts seem to have renounced any interpretation of history which might have the effect of "constitutionalizing" contemporary professional organization. In Re: Klein and the Law Society of Upper Canada (1985), 50 O.R. (2d) 118 at 157 (Div. Ct.), Callaghan J. said: "The Law Society is a statutory authority exercising its jurisdiction in the public interest and is not, as was suggested in argument, a private body whose powers derive from some vague form of contract or articles of association found in the mists of antiquity." (I am grateful to Dr. Andrew Brockett, Research Director, Law Society of Upper Canada, for drawing this to my attention.) Similarly, Regulating Professions and Occupations (Winnipeg: Manitoba Law Reform Commission, Report \#84, October 1994) authoritatively rejects any notion that professional organizations are anything other than creatures of the state. This report, issued by a distinguished and highly respected team of law reform commissioners (Clifford Edwards, John Irvine, Gerald Jewers, Eleanor Dawson, Pearl McGonigal), provides extraordinary insights into contemporary professional regulation in Canada. 
province. ${ }^{181}$ The Ontario law society, first recognized by Imperial statute in 1787, has had full power and authority to "discipline" lawyers in the jurisdiction since that time. ${ }^{82}$ Canadian law societies routinely claim continuity of corporate existence since at least the time of their originating statute notwithstanding significant changes in the legislative framework of law society practice since that time.

(4) Because the law societies originate not in statute but in private bodies in the distant past in England, they are not "public" bodies. They do not, therefore, exercise public power. ${ }^{83}$

(5) Law societies have been given "self-governing status" in order to protect lawyers - and hence, their clients - from control by "the state." 84 The state is the most fundamental and pervasive threat to individual rights and liberties; the historic and unique responsibility of lawyers is to protect "rights" (principally, one presumes, against encroachment by the state). ${ }^{85}$

81 Briefings, supra note 17 at 1.

22. Submission to Professional Organizations Committee, supra note 25 at 6. Quoting the Law Society of Upper Canada's own minutes of 1833, involving the disciplinary process of "Doyle": "the power of degradation and expulsion as well as all other powers belonging to the Inns of Court in England are also by law vested in this Society." Although this in fact implies a limited and highly contested disciplinary power, this fact is not widely appreciated by Canadian law societies which have assumed a long-standing continuity of almost unconstrained power over their members.

The limited and contested disciplinary power vested in the English Inns of Court and in Canadian law societies in the nineteenth century is apparent. See: W.W. Pue, "Moral Panic at the English Bar: Paternal vs. Commercial Ideologies of Legal Practice in the 1860's" (1990) 15 L. \& Soc. Inq. 49 [formerly American Bar Foundation Research Joumal]; W.W. Pue, "Exorcising Professional Demons: Charles Rann Kennedy and the Transition to the Modern Bar" (1987) 5 L. \& Hist. Rev. 135 [hereinafter "Demons"]; W.W. Pue, "Rebels at the Bar: English Barristers and the County Courts in the 1850's" (1987) 16 Anglo-American L. Rev. 303 [hereinafter "Rebels at the Bar"]; W.W. Pue, "Becoming 'Ethical': Lawyers' Professional Ethics in Early Twentieth Century Canada" (1991) 20 Man. L.J. 227 (also published in Glimpses, supra note 32 at 237) [hereinafter "Becoming Ethical"].

83 Submission to Professional Organizations Committee, ibid. at 4-7. This is contradicted in McRuer Commission, supra note 25 , which asserted that "the granting of self-government is a delegation of legislative and judicial functions and can only be justified as a safeguard to the public interest." (quoted in Proposed Role Statement, supra note 25 at 8). See also Regulating Professions and Occupations, supra note 80.

Contra "Bishop Submission," supra note 22 at 9, arguing that law societies are created by statute as "self-regulatory" organizations rather than bodies exercising "delegated" powers. No authority is cited for this proposition.

84 Briefings, supra note 17 at 1; "Bishop Submission," ibid. at 2-3, 5; "The Self Governing Profession," supra note 15 at 1.

8s Submission to Professional Organizations Commintee, supra note 25 at 3 (cited in tum in Proposed Role Statement, supra note 25; Ombudsman, supra note 25 at 11; and paraphrased without attribution in "Bishop Submission," ibid. at 5). See also Brief to the Minister - Newfoundland, supra note 15 at 3, 6; Manitoba Response, supra note 18 at 3-5. 
(6) Freedom, democracy and the "rule of law" rest on the independence of lawyers from state control. ${ }^{86}$ In some formulations, the need for independence is not expressed in relation to the state only: "It has long been recognized that lawyers must be independent of external influence and pressure if they are to carry out their responsibilities properly." ${ }^{87}$ In one formulation; "It is the process of independent advocacy in individual cases ... that has raised us up from slavery." 88

(7) Constitutional governance requires the existence of a self-governing, organized legal profession. ${ }^{89} \mathrm{~A}$ "lawyer's right to practice and to earn a living" must rest "in the hands of his or her professional association." ${ }^{90}$ The source of authority for this constitutional arrangement is unclear but is variously associated with the Glorious Revolution, ${ }^{91}$ mysterious developments in England in the fourteenth century ${ }^{92}$ or unnamed historical tradition.

An independent judiciary cannot exist without an independent bar. ${ }^{93}$

Briefings, supra note 17 at 1; "Bishop Submission," ibid. at 2; Estey J. in A.-G. v. L.S.B.C., supra note 77 (quoted in turn in "Bishop Submission," ibid. at 40; Spence Address, supra note 26 at 6; Brief to the Minister - Newfoundland, ibid. at 6; Report of the Professional Organizations Committee, ibid. at 26 (cited in turn by lacobucci J., in Pearlman, supra note 62 at 118-19; in Brief to the Minister - Newfoundland, ibid. at 8 and also cited in Proposed Role Statement, ibid. at 4; Ombudsman, ibid. at 13)). Spence Address, ibid. at 4. Arguing in defence of an expansive interpretation of lawyers' monopoly in the provision of "legal services," the Law Society of Upper Canada adopted the position that "an economically sound legal profession at all levels is necessary if the profession is to be in a position to retain its independence not only from government intrusion but from overreliance on a few clients and subservience to their demands." (Submission to Professional Organizations Committee, supra note 25 at 30).

To similar effect, Taylor argues, in M.R. Taylor, "The Independence of the Bar" (1981) 39 Advocate 209 at 216 that "The bar must not only demand independence but must practice it. Members of the bar cannot afford to allow themselves to be dependent, whether on particular clients, or particular types of client, or a particular scale of remuneration. The bar must, of course, serve the public as a whole. It can do so only if individual members of the bar keep themselves free to discharge that obligation."

Taylor, ibid. at 209, as cited in "Bishop Submission," supra note 22 at 10 [emphasis omitted].

"Bishop Submission," ibid. at 8-9.

lbid. at 2.

Ibid.; Taylor, supra note 87; see also W.R. Lederman, "The Independence of the Judiciary" (1956) 34 Can. Bar. Rev. 769.

Submission to Professional Organizations Committee, supra note 25 at 5: "the English Inns of Court which find their origins well back in the fourteenth century were transported from the old country to the new, with the adaptation required to meet local conditions."

"Bishop Submission," supra note 22 at 2; Report of Professional Organizations Committee, supra note 25 at 26. This canonical passage is cited in turn by lacobucci J. in Pearlman, supra note 62 at 118-19, cited in turn in Brief to the Minister - Newfoundland, supra note 16 at 8; (also cited in Proposed Role Statement, supra note 25 at 13; Ombudsman, supra note 25 at 12, 13; Submission to Professional Organizations Committee, supra note 25 at 3). 
(9) The independence of the legal profession is, for practical purposes, indistinguishable from the question of self-governance. "Self-governance" serves to ensure the independence of lawyers. ${ }^{94}$

(10) The legal profession has, in the public interest, "over many years, developed a comprehensive code of ethical standards that its members must follow."95

(11) The governing bodies of the legal profession have historically acted to protect the public interest. ${ }^{96}$

(12) Professional rhetoric routinely elides the legal profession and the legal system as a whole, as in the Law Society of Alberta assertion that "a mechanism or a policy for government interference or influence on the affairs of a self-governing legal system is an unjustified and unnecessary encroachment....".97

We have here several of the key elements of myth as identified earlier in this article. Lawyers' professional discourses provide an account of "origins and identity ... of a group" (the legal profession originates in England in ancient time); the myth provides "the basis for claiming ... a superiority for the group" (the legal profession is unique in protecting the rights of subjects); the point of origin is rendered sacred, transcendent (the continuity between twentieth century Canada and thirteenth century England) beyond profane experience (which, knowing no better, would seek "origins" only in provincial originating statutes). The frequency with which mythic origins are invoked in contemporary professional discourses well illustrates that, for lawyers, myth provides "guidance and orientation to a reality which is perceived and lived through myth."

\section{POLICY IMPLICATIONS OF MYTH}

Importantly, professional myth "sets the limits of the world, of what can be meant and done" in many ways and in all aspects of professional life. Any number of proposals with regard to the regulation of the legal profession have, in recent years, been said to contravene historically derived principles. These have included proposals for:

- any "transfer of regulation-making authority to the Lieutenant Governor in Council"198 [including] "the authority of the Lieutenant Governor in Council

94 Spence Address, supra note 26 at 12.

95 Briefings, supra note 17 at 3. In the Law Society of Saskatchewan formulation, "The feature which distinguishes a profession from a trade is that a profession has, over many years, developed a comprehensive code of ethical standards to which its members ascribe." ("The Self Governing Profession," supra note 15 at 5). 
to approve, amend, or enact regulations governing the day to day affairs of the legal profession...." 99

- an "increase of Lay Benchers to one-third of the total Benchers" [i.e., five] in Newfoundland ${ }^{100}$ or any increase in the number of Lay Benchers above two in Alberta. ${ }^{101}$

- the appointment of Lay Benchers by the Lieutenant-Governor-in-Council. ${ }^{102}$

- $\quad$ "including Lay Benchers on discipline hearing panels." 103

- abolishing the practice of naming "the Attorney-General [or the Registrar of the Supreme Court] as a bencher by virtue of Office." 104

- allowing direct appeal of decisions of disciplinary adjudication panels to the Court of Appeal, rather than through intermediate internal appeal to the Benchers as a whole. ${ }^{105}$

- $\quad$ granting complainants a right to appeal law society disciplinary decisions to the courts. ${ }^{106}$

- enacting legislation to establish a structure of regulation respecting contingency fees. $^{107}$

assigning responsibility for the overview of the legal profession to any minister of the Crown other than the Attorney-General. ${ }^{108}$

- holding counsel responsible for their undertakings regarding the allocation of court time (in this case a direction by the Court of Appeal of Alberta "that all counsel remain strictly within their estimated times for argument or face a

Ibid. at 22. It is interesting that the Ontario law society on the other hand expresses pride in the fact that it is "accountable" to the public through mechanisms including an arrangement in which "regulations made by the Law Society are subject to approval by the Lieutenant Governor in Council." (Ombudsman, supra note 25 at 18).

100 Brief to the Minister - Newfoundland, supra note 16 at 2, 13-14.

101 "Bishop Submission," supra note 22 at 11 . There are now three non-lawyer benchers in Alberta.

${ }^{102}$ Brief to the Minister - Newfoundland, supra note 16 at 3. This is, however, the method of appointment used in Ontario where it is thought to be appropriate to protect "the public interest" by the Law Society of Upper Canada (Proposed Role Statement, supra note 25 at 8). Saskatchewan and British Columbia also appoint lay-benchers in this way and executive appointment by one or another route is the norm in Alberta (A.-G. appointment), Prince Edward Island (Executive council), the Northwest Territories ("Government"), and Yukon (Executive Council) (Brief to the Minister - Newfoundland, ibid. at 11-12).

Brief to the Minister - Newfoundland, ibid. at 16. In sharp contrast, however, the Ontario law society has called for the creation of "the position of Complaints Commissioner to be appointed by a committee representative of the government, the Law Society and the public." (Ombudsman, supra note 25 at 21 ).

Brief to the Minister - Newfoundland, ibid. at 15.

Ibid. at 16-18.

"Bishop Submission," supra note 22 at 12.

107 Brief to the Minister - Newfoundland, supra note 16 at 18-22. The logic of the Law Society of Newfoundland on this point is interesting:

To the extent that this legislation would dictate or have an effect on the conduct of litigation before the Courts, it may infringe upon the freedom of the legal profession to conduct litigation or not as appropriate. If it can be said that this legislation would so infringe upon the independence of the legal profession by virtue of the fact that lawyers are officers of the Court, it may be said to consequently infringe upon the independence of the judiciary. (ibid. at 21-22). 
personal penalty of costs associated with any resulting adjournments of any other appeals which had been set for consideration..." ${ }^{109}$ ).

- the adoption of a mechanism whereby the membership of the law society at large would participate directly in the approval of rules and regulations governing the profession. ${ }^{110}$

- any narrowing of the protection of lawyers' economic monopoly provided under so-called "unauthorized practice" provisions."

- review of the law society by the provincial Ombudsman. ${ }^{112}$

- the creation of a public defender system. ${ }^{113}$

- $\quad$ an increase in court fees. ${ }^{114}$

- the creation of any "central government bureaucracy, department or commission to oversee the legal profession and significantly alter the current form of self-government for lawyers...." 115

- the creation of "judicial conduct committees" or the development of a "written code of judicial conduct" — said to be an American "horror story." 116

All of this is heavy duty for professional myth. Let us now probe the adequacy of our myths as measured against the standard of historical research.

\section{PROFESSIONAL HISTORIAN'S FALLACIES}

Unfortunately, the ways in which history is used in contemporary Canadian lawyers' apologetics fails miserably whether evaluated by the standards of logic governing historical research or by the substantive historical findings reported in published scholarship relating to the history of the legal professions.

One of the most striking features of professional myth in Canada is the way in which "historical" accounts of the origins of the contemporary structures of regulation in Canada are offered in the place of rigorous policy analysis. David Hackett Fischer, author of the influential book Historians' Fallacies, explains this as one of several "fallacies of narration":

The genetic fallacy mistakes the becoming of a thing for the thing which it has become. In other words, it is the erroneous idea that "an actual history of any science, art, or social institution can take the place of a [nontemporal] logical analysis of its structure."

C.B. Davison, "Letters to the Editor, Re: Court of Appeal Directive Concerning Time Estimates" Law Society of Alberta/Canadian Bar Association, Alberta Branch, Newsletter (January/February 1994) 10.

$110 \quad$ "Bishop Submission," supra note 22 at 20.

IIII Ibid. at 22.

112 Ombudsman, supra note 25 at 2; Submission to Professional Organizations Committee, supra note 25 at 10. This review mechanism is already in place in British Columbia.

113 Scott Address, supra note 26 at 20.

is4 Ibid.

115 Manitoba Response, supra note 18 at 5

116 Scott Address, supra note 26 at 22-27. 
The most hateful forms of the genetic fallacy are those which convert a temporal sequence into an ethical system - history into morality. This pernicious error was embedded in a movement called historicism, which flourished in Germany during the period 1790-1930.... Historicism was many things to many people, but in a general way its epistemology was idealist, its politics were antidemocratic, its aesthetics were romantic, and its ethics were organized around the nasty idea that whatever is becoming, is right. ${ }^{117}$

The "genetic fallacy" pervades Canadian lawyers' apologetics. It is, perhaps, the single most important failing of what passes for analysis in contemporary legal writing.

Beyond this, most of Fischer's "fallacies of narration" appear with some frequency in Canadian lawyers' apologetics. Time and space preclude a full development or illustration of these. For present purposes it suffices to note that professional apologetics is chock-full of errors in historical logic including fallacies of anachronism, ${ }^{118}$ and of presentism ${ }^{119}$ in all its mutations ${ }^{120}$ (including the very crudest form of "Whig" history), ${ }^{121}$ the antiquarian fallacy, ${ }^{122}$ the fallacies of tunnel history $^{123}$ and false periodization, ${ }^{124}$ the telescopic fallacy, ${ }^{125}$ the interminable

D.H. Fischer, Historians' Fallacies: Toward a Logic of Historical Thought (New York: Harper Colophon Books, 1970) at 155-56, quoting M.R. Cohen \& E. Nagel, An Introduction to Logic and the Scientific Method (New York: Harcourt Brace, 1934) at 388-90.

"[T]he description, analysis, or judgment of an event as if it occurred at some point in time other than when it actually happened." (ibid. at 132-33).

"[A] complex anachronism, in which the antecedent in a narrative series is falsified by being defined or interpreted in terms of the consequent. Sometimes called the fallacy of nunc pro tunc, it is the mistaken idea that the proper way to do history is to prune away the dead branches of the past, and to preserve the green buds and twigs which have grown into the dark forest of our contemporary world." (ibid. at 135).

In one example cited by Fischer, "backward projections of present phenomena so grossly distorts the past that the reader receives an utterly erroneous idea of events in earlier periods, and of tendencies in his own as well." (ibid. at 136).

121 "No discussion of presentism in history can be complete without the classic example of the "Whig interpretation of history,' which has been defined by Herbert Butterfield the 'tendency in many historians to write on the side of Protestants and Whigs, to praise revolutions provided they have been successful, to emphasize certain principles of progress in the past and to produce a story which is the ratification if not the glorification of the present." (ibid. at 139, quoting $\mathrm{H}$. Butterfield, "Preface" in The Whig Interpretation of History (London: G. Bell and Sons, 1931)).

"An antiquarian is a collector of dead facts, which he stuffs full of sawdust and separately encloses in small glass cases. Often, he is a gentleman (or lady) of respectable origins who is utterly alienated from the present. The past serves him as a sanctuary from a sordid world which he neither accepts nor understands." (Fischer, ibid. at 140).

"[I]dentified by J. H. Hexter, and so-named after the tendency of many historians to 'split the past into a series of tunnels, each continuous from the remote past to the present, but practically self-contained at every point and sealed off from contact with or contamination by anything that was going on in any of the other tunnels. At their entrances these tunnels bore signs saying diplomatic history, political history, institutional history, ecclesiastical history, intellectual history, military history, economic history, legal history, administrative history, art history, colonial history, social history, agricultural history, and so on, and so on.'" (ibid. at 194-95).

125 Which "makes a long story short. It appears in interpretations which reduce an extended trend to a momentary transformation." (ibid. at 147). 
fallacy, ${ }^{126}$ the fallacy of archetypes, ${ }^{127}$ the static fallacy, ${ }^{128}$ the fallacy of presumptive continuity, ${ }^{129}$ and, especially, the didactic fallacy. ${ }^{130}$

Being lawyers, professional apologists are peculiarly susceptible to the logical error of "argument ad verecundiam," ${ }^{131}$ which involves reliance on authority rather than logic to bludgeon those who may hold opposing views into submission. Argument ad verecundiam appears in most of its possible forms in contemporary professional apologetics: "never use a little word when a big one will do"; ; 132 padding "a lean thesis with fat footnotes which are irrelevant, or superfluous"; 133 "the use of quotations ... employed for forensic rather than empirical purposes"; ${ }^{134}$ and the excessive reliance on "the authority of the printed page," involving a tendency to believe anything found in written form. ${ }^{135}$

For fear of myself falling into the error of argument ad verecundiam - by sustaining "a thesis ... by the length of its exposition"136 — I will decline the opportunity to engage in any detailed measurement of our apologetic literatures against the standards of historical logic. In general, canonical statements are most suspect in this regard a coincidence which taints the entire project. These literatures lapse into teleological functionalism and perpetuate myths as to continuity with an ancient English tradition along with myths as to what that tradition involves. They "translate" eighteenth century statutes into a language of democracy and individual right. Though pleasing to contemporary sensibilities, this strategy is misleading in the extreme for the

Which "makes a short story long, or a long story longer than it ought to be. It is a temporal form of a false extrapolation - a developmental trend stretched beyond the breaking point." (ibid. at 149-50).

"[C]onceptualizing change in terms of the re-enactment of primordial archetypes which exist outside of time. It is a method in which an event acquires meaning as a re-enactment of some aboriginal and atemporal model.... The myth of the return is an antithesis to time, change, and history itself. When it is used by a historian to conceptualize his subject, then it becomes a fallacy, for the myth implies that what is real does not change." (ibid. at 150-51). "[A]ny attempt to conceptualize a dynamic problem in static terms. This form of error represents an intermediate stage of historical consciousness, in which change is perceived merely as the emergence of a nonchanging entity ... a good many liberal textbook historians of the American republic tend to conceptualize their dynamic subject in terms of the unfolding of a static idea of democratic society, which slowly reveals itself through three centuries, without ever really changing in the process. The result is a historiographical equivalent of the Dance of the Seven Veils...." (ibid. at 153).

"[T] fundamental forms of error which came to mind in a reading of Barrington Moore's Social Origins of Dictatorship and Democracy. Moore criticizes his colleagues for an assumption of social inertia in their work.... But I wonder if Moore has committed the counterfallacy of presumptive change. They are both equally indefensible." (ibid. at 154-55). "[T] he attempt to extract specific 'lessons' from history, and to apply them literally as policies to present problems, without regard for intervening changes." (ibid. at 157). Ibid. at 283.

Ibid. at 285.

Ibid. at 286.

Ibid. at 286-87.

Ibid. at 290.

Ibid. at 287. 
"translation" involves the major historical gaff of conflating eighteenth century constitutionalism with late twentieth century democracy. ${ }^{137}$

Canonical statements are also rife with the linking of ideas which obscure historical experience while purporting to reflect it. One example developed from a passage widely cited in professional apologetics will suffice for illustration and also provide a point of connection with the next portion of this article - which provides $a$ narrative of what historical research concerning the legal profession has to say to us.

The independence of the Bar from the state in all its pervasive manifestations is one of the hallmarks of a free society. Consequently, regulation of these members of the law profession by the state must, so far as by human ingenuity it can be so designed, be free from state interference.... The public interest in a free society knows no area more sensitive than the independence, impartiality and availability to the general public of the members of the Bar and through these members, legal advice and services generally. The uniqueness of position of the barrister and solicitor in the community may well have led the province to select self-administration as the mode for administrative control over the supply of legal services throughout the community. Having said all that, it must be remembered that the assignment of administrative control to the field of self-administration by the profession is subject to such important protective restraints as the taxation officer, the appeal to the courts from action by the Benchers, the presence of the Attorney General as an ex-officio member of the Benchers and the legislative need of some or all of the authority granted to the Law Society. ${ }^{138}$

It is easy to allow a passage such as this to wash over us without much critical assessment. It sounds so fine, so logical, so necessary. In fact, however, the passage consists of one unexplained logical leap piled upon another. It deconstructs itself completely on what is called a "literal" reading of the text and disintegrates entirely when the actual historical record of the legal professions in the common law world is juxtaposed with assumed historical trajectories.

At the most elementary level it should be jarring to any critical reader to be told in one sentence that " $\mathrm{x}$ " or " $\mathrm{y}$ " or " $\mathrm{z}$ " must, for tremendously important political reasons, be insulated from state interference only to read, just three sentences later, a celebration of the direct participation of a member of cabinet (the Attorney-General) and of the legislature in that very sphere of activity! The fact that, as lawyers, we do not notice this should be a source of great embarrassment to us.

So too should the leaps of logic involved in simultaneously celebrating the virtues of an "independent" barristers' profession and the creation of a governing body with extensive powers of rule-making and punishment. A bare dictionary definition reveals 
"independent" to mean "not depending on authority"; ${ }^{139}$ yet the statutory creation of governing bodies which exist only to subject barristers to the authority of a political structure (albeit one not directly part of the "state") is celebrated as mysteriously enhancing rather than infringing upon the independence of barristers. The fact that it is probably very difficult for most modern Canadian lawyers to even perceive a logical flaw here only shows how entirely captive we are to a particular mentality. This was not always the case. In England throughout the nineteenth century, it was widely thought that in order for barristers to provide the political benefits associated with an independent legal profession they would need to be independent from the organized bar, not just from the state. ${ }^{140}$ That this is not widely known is testimony to the powerful silencing capability of "winners' history" in the professional realm.

My reference to English practice in the nineteenth century is not, in this context, merely the conditioned reflex of a colonial suffering a severe case of cultural cringe. Our legal professions widely celebrate the English inheritance without knowing what it is we supposedly inherited. In a third compression of historical experience, Estey J. confused the histories and functions of two quite distinct English legal professions, treating the barristers' and solicitors' professions as indistinguishable antecedents to the contemporary unified legal profession in Anglo-Canada. The leap in logic and in history is accomplished in short space, only two sentences separating the idea that an independent bar is "one of the hallmarks of a free society" and the quite distinct emphasis on the "uniqueness of position of the barrister and solicitor...." Earlier generations of Canadian lawyers well understood that "the legal profession in Canada is made up of two distinct professions with different duties, different responsibilities and liabilities, different history and traditions, and subject to different rules." ${ }^{141}$ But our real historical memory is short.

No student of the history of English lawyers would ever confuse the professions of barrister and solicitor in this way. To this day those professions are distinct. They perform different functions, are qualified through different professional structures and have emerged through different historical trajectories. There may indeed be good reason to seek to enhance or to celebrate the "independence" of an advocates' profession. With the notable exception of the English profession, ${ }^{142}$ it may be the case that an active advocates' profession has in fact done much to advance the development of political

H.W. Fowler \& F.G. Fowler, The Concise Oxford Dictionary of Current English, 7th ed. (Oxford: Clarendon Press, 1983).

See: W.W. Pue, "Demons," supra note 82; "Rebels at the Bar," supra note 82; "Moral Panic," supra note 82; Inns of Court, The Speech and Reply of D.W. Harvey Esq., M.P. on the 14th of June, 1831, in the House of Commons (London: James Ridgway, 1832).

C.J.M. Mathers, "Legal Ethics" (Address to Manitoba Bar Association, 19 May 1920) at 6 [Archive of Manitoba Legal History, Acc. No. 49.A222].

C. Robbins, Eighteenth-Century Commonwealthman (Cambridge: Harvard University Press, 1959) argues that in George II's England, "Lawyers ... were protectors of tradition and contributed little to the development of liberalism in any way." (ibid. at 294-95). See also P. Lucas, "Collective Biography of Students and Barristers of Lincoln's Inn, 1680-1804: A Study in the 'Aristocratic Resurgence' of the Eighteenth Century" (1974) $46 \mathrm{~J}$. Mod. Hist. 242. I am grateful to Wilfrid Prest for bringing these sources to my attention. 
or economic liberalism ${ }^{143}$ through speech and actions in the courtroom. It takes a peculiarly rose-tinted view of the world to find such heroism in the mundane world of solicitors' transactions - past or present. There is a tremendous leap of faith involved in arguing from the standpoint of a political appreciation of the independence of advocates for a regulatory regime which subjects both advocate and professional form-filler to the same regulatory regimen. In Canada, barristers and solicitors become one. That one, it seems, is the barrister.

The same sentence which produces this elision of distinct professions also provides us with an historical fiction which stands in place of historical enquiry. It is simply assumed that "the province" appreciated the "uniqueness" of our diune legal profession and therefore opted to create a system of "self-administration." This assumed history suppresses the reality of conflict, disagreement and negotiation which has accompanied many changes in the structures of legal professionalism in Canada. It obliterates human agency or self-interest altogether, foreclosing rather than opening up historical enquiry. Like so much of professional apologetics, it denies history by assuming that what is has always been: it is presumed that nothing significant has happened in professional organization or structure or politics since long-gone days when "self-governance" emerged, fully formed. Such assumptions are the antithesis of the historical imagination.

\section{HISTORIANS OF LAWYERS}

Not all accounts of the legal profession in history are so much distorted by the pressing day-to-day concerns of contemporary institutions. While it is regrettable that more primary historical research on the history of the organized legal profession is not underway, it is much more seriously a matter of regret that contemporary professional apologetics is produced in apparent ignorance of the scholarly work which is available. Many fine historians have addressed aspects of the history of the legal profession in Canada, ${ }^{144}$ the United States, ${ }^{145}$ Australia, ${ }^{146}$ and the United Kingdom. ${ }^{147}$

L. Karpik \& T. Halliday, eds., Legal Professions and Political Liberalism [forthcoming]; L. Karpik, "Lawyers and Politics in France, 1814-1950: The State, the Market, and the Public" (1988) 13 L. \& Soc. Inq. 707.

See e.g. C. Backhouse, "To Open the Way for Others of My Sex: Clara Brett Martin's Career as Canada's First Woman Lawyer" (1985) I C.J.W.L. 1; "Elegant Web," supra note 69; "Juvenile Advocate," supra note 69; "Bliss Brothers," supra note 32; "Slavery," supra note 32; "Uniacke," supra note 32; "Judicial Crisis," supra note 32; "Transformation," supra note 32; W.F. Bowker, "Extra-Judicial Writing: The Alberta Law Quarterly and the Alberta Law Review" (1980) 18 Alta. L. Rev. 458; W.F. Bowker, "Fifty-five Years at the Alberta Bar: George Hobson Steer, Q.C." (1982) 20 Alta. L. Rev. 242; W.F. Bowker, (M. Bowker, ed.) A Consolidation of Fify Years of Legal Writings by Wilbur F. Bowker, 1938-1988 (Edmonton: Faculty of Law, University of Alberta, 1989); Osgoode Society, "Interview with W.F. Bowker" in Osgoode Society Oral History Project 1987-88 (Ontario Archives); W.F. Bowker, "Stipendiary Magistrates and Supreme Court of the North-West Territories, 1876-1907" (1988) 26 Alta. L. Rev. 245; W.F. Bowker, "The Honourable Horace Harvey, Chief Justice of Alberta" (1954) 32 Can. Bar Rev. 933, 1118-39 (republished in W.F. Bowker, (M. Bowker, ed.) A Consolidation of Fifty Years of Legal Writings, 1938-1988, ibid. at 59-117); W.F. Bowker, "Which is the Chief Chief Justice - David Lynch Scott or Horace Harvey?" (1992) 30 Alta. L. Rev. 1179; Memo of W.F. Bowker to L.D. Hyndman (24 July 1981); D. Brawn, "What Differences Did Lawyers Make? Image and Reality in Manitoba, 1909-1919" (Paper presented to Canadian Association of Law Teachers Annual Conference, 1994) 
[unpublished]; C. Cole, "After the Crisis: Legal Education at Osgoode Hall, 1949-1957" in Proceedings of the Canadian Law in History Conference, vol. 3 (Ottawa: Department of Law, Carleton, 1987); C. Cole, "'A Hand to Shake the Tree of Knowledge': Legal Education in Ontario, 1871-1889" (1986) 17 Interchange; C. Cole, "A Developmental Market: Competition and Professional Standards in the Ontario Legal Profession, 1881-1936" (1983) 6 Can.-U.S. L.J. 125; C. Cole, 'A Learned and Honourable Body': The Professionalization of the Ontario Bar, 1867-1929 (Ph.D. Thesis, University of Western Ontario, 1987); C. Cole, "McCarthy, Osler, Hoskin, and Creelman, 1882 to 1902: Establishing a Reputation, Building a Practice" in C. Wilton, ed., Beyond the Law: Lavyers and Business in Canada, 1830 to 1930 (Toronto: The Osgoode Society, 1990) 149; H. Dick, Lawyers of Mennonite Background in Western Canada, 1900-1940: Two Cultures in Conflict (Winnipeg: Legal Research Institute, 1993) [hereinafter Two Cultures]; D. Gibson, "An Anecdotal Sampler" in C. Harvey, ed., The Law Society of Manitoba 1877-1977 (Winnipeg: Peguis, 1977) 191; D. Gibson, L. Gibson \& C. Harvey, Attorney for the Frontier: Enos Stutsman (Winnipeg: University of Manitoba Press, 1983); D. Gibson \& L. Gibson, Substantial Justice: Law and Lawyers in Manitoba, 1670-1970 (Winnipeg: Peguis, 1972); L. Gibson, "A Brief History of the Law Society of Manitoba" in C. Harvey, ed., The Law Society of Manitoba, 1877-1977, ibid. at 28; P. Girard, "Bulmer," supra note 32; "Renaissance," supra note 32; "Maritime," supra note 32; C. Harvey, ed., Chief Justice Samuel Freedman: A Great Canadian Judge (Winnipeg: Law Society of Manitoba, 1983); C. Harvey, "Some Benchers and Secretaries" in C. Harvey, ed., The Law Sociery of Manitoba, 1877-1977, ibid. at 222; C. Harvey, "Women in Law in Canada" (1970-71) 4 Man. L.J. 9; L. Knafla, "From Oral Tradition to Written Memory: The Common Law Tradition in Western Canada" in L. Knafla, Law and Justice in a New Land (Calgary: Carswell, 1986) 31; Romney, "Trial by Jury," supra note 69; "Canadian Statism," supra note 69; "Types Riot," supra note 69; "Fantasies," supra note 69; P. Sibenik, "The Black Sheep': The Disciplining of Territorial and Alberta Lawyers, 1885-1928" (1988) 3 Can: J.L. \& Soc. 109; P. Sibenik, The Doorkeepers: The Governance of Territorial and Alberta Lawyers, 1885-1928 (M.A. Thesis, University of Calgary, 1984) [hereinafter Governance]; P.M. Sibenik, "Doorkeepers: Legal Education in the Territories and Alberta, 1885-1928" (1990) 13 Dalhousie L.J. 419; J.S. Swainger, "Ideology, Social Capital, and Entrepreneurship: Lawyers and Business in Red Deer, Alberta, 1900-1920" in C. Wilton, ed., ibid.; J.S. Swainger, Law in the Parkland: A History of the Red Deer Judicial District, 1907-1920 (M.A. Thesis, University of Calgary, 1987); C. Wilton, ed., ibid:; R. Wyllie, 'These Legal Gentlemen': Becoming Prominent in Manitoba, 1870-1900 (Ph.D. Thesis, University of Alberta, 1989).

A. Abbott, The System of Professions: An Essay on the Division of Expert Labor (Chicago: University of Chicago Press, 1988); A. Abbott, "Jurisdictional Conflicts: A New Approach to the Development of the Legal Professions" (1986) A.B.F. Res. J. 187; R.L. Abel, "Between Market and State: The Legal Profession in Turmoil" (1989) 52 Modem L. Rev. 285; R.L. Abel, "The Rise of Professionalism" (1979) 6 Brit. J.L. \& Soc. 82; J.S. Auerbach, "Enmity and Amity: Law Teachers and Practitioners, 1900-1922" in D. Fleming \& B. Bailyn, eds., Law in American History (Boston: Little Brown, 1971) 549; J.S. Auerbach, Unequal Justice: Lawyers and Social Change in Modern America (New York: Oxford University Press, 1976); J.C. Foster, The Ideology of Apolitical Politics: The Elite Lavyer's Response to the Crisis in American Capitalism, 1870-1920 (New York: Associated Faculty Press, 1987); R.W. Gordon, "Legal Thought and Legal Practice in the Age of American Enterprise, 1870-1920" in G. Geison, ed., Professions and Professional Ideologies in America (Chapel Hill: University of North Carolina Press, 1984); R.W. Gordon, "The Ideal and the Actual in the Law': Fantasies and Practices of New York City Lawyers, 1870-1910" in G.W. Gawalt, ed., The New High Priests: Lawyers in Post-Civil War America (Westport, Conn.: Greenwood Press, 1984); R.W. Gordon, "Brendan Brown Lecture: Critical Legal Studies as a Teaching Method" (1989) 35 Loyola L. Rev. 383; R.W. Gordon, "Corporate Law Practice as a Public Calling" (1990) 49 Maryland L. Rev. 255; R.W. Gordon, "Critical Legal Histories" (1984) Stan. L. Rev. 57; R.W. Gordon, "Historicism in Legal Scholarship" (1981) 90 Yale L.J. 1017; R.W. Gordon, "Law and Disorder" (1989) 64 Indiana L.J. 803; R.W. Gordon, "The Independence of Lawyers" (1988) Boston U. L. Rev. 1; T.C. Halliday, "Six Score Years and Ten: Demographic Transitions in the American Legal Profession, 1850-1980" (1986) 20 L. \& Soc. Rev. 53; T. Halliday, Beyond Monopoly: Lawyers, State Crises, and Professional Empowerment 
It would be rash - indeed, ahistorical - to attempt to construct any singular storyline from these disparate literatures dealing, as they do, with many professional bodies on three continents over four centuries. Nonetheless, at least three important points sit uneasily with history-as-Canadian-lawyers-would-like-it-to-be.

(Chicago: University of Chicago Press, 1987); T.C. Halliday, Formative Professionalism \& the Three Revolutions: Legal Careers in the Chicago Bar, 1850-1900 (A.B.F. Working Papers 8715); T. Halliday, Legal Education \& the Rationalization of Law: A Tale of Two Countries-the United States \& Australia (A.B.F. working papers 8711); T.C. Halliday, Legal Professions \& Politics: Neo-corporatist Variations on the Pluralist Theme of Liberal Democracies (A.B.F. Working Papers 8710); T.C. Halliday, M.J. Powell \& M.W. Granfors, Minimalist Organizations: Vital Events in State Bar Associations, 1870-1930 (A.B.F. Working Papers 8713); T.C. Halliday, M.J. Powell \& M.W. Granfors, "Minimalist Organizations: Vital Events in State Bar Associations, 1870-1930" (1987) 52 Am. Soc. Rev. 456; T.C. Halliday, M.W. Granfors \& M.S. Powell, Organizations Between States \& Markets: Explaining the Bar Unification Movement 1915-1950 (A.B.F. Working Papers 8809); T.C. Halliday \& M.W. Granfors, Professional Passages: Caste, Class \& Education in the 19th Century Legal Profession (A.B.F. Working Papers 8714); T.C. Halliday, The Fractured Profession: Structural Impediments to Collective Action by the Australian Legal Profession (A.B.F. Working Papers 8712); B.J. Hibbits, "Our Arctic Brethern: Canadian Law and Lawyers as Portrayed in American Legal Periodicals, 1829-1911" (1994) 2 U.B.C. Legal Hist. Papers; B.J. Hibbits, "Coming to Our Senses: Communication and Legal Expression in Performance Cultures" (1992) 42 Emory L.J. 873; M.J. Horwitz, The Transformation of American Law, 1870-1960 (Cambridge: Harvard University Press, 1977); M.J. Osiel, "Lawyers as Monopolists, Aristocrats, and Entrepreneurs" (1990) 103 Harv. L. Rev. 2009; M.S. Powell, From Patrician to Professional Elite (New York: Russell Sage Foundation, 1988).

R. McQueen, "The Law Institute of Victoria 1885-1930 - 'A Very Powerful and Far Reaching Trade Union'" Canadian Legal History Project Working Paper 1993-3; J.R.S. Forbes, The Divided Legal Profession in Australia: History, Rationalisation and Rationale (Sydney: The Law Book Co., 1979).

R.L. Abel, Legal Profession in England and Wales (Oxford: Blackwell, 1988); Abel, "The Rise of Professionalism," supra note 145; J.H. Baker, "Counsellors and Barristers: An Historical Study" [1969] Cambridge L.J. 205; J.H. Baker, History of the Order of Serjeants at Law (Ph.D. Thesis, University of London, 1968); J.H. Baker, The Legal Profession and the Common Law: Historical Essays (London: Hambledon Press, 1986); R. Cocks, Foundations of the Modern Bar (London: Sweet and Maxwell, 1983); R. Cocks, "Victorian Barristers, Judges and Taxation: A Study in the Expansion of Legal Work" in Rubin \& D. Sugarman, Law, Economy and Society (Abingdon, England: Professional Books, 1984) 445; W.R. Prest, "Why the History of the Professions is Not Written" in Rubin \& Sugarman, ibid. at 300; W.R. Prest, ed., Lawyers in Early Modern Europe and America (London: Croom Helm, 1981); W.R. Prest, "Rethinking the Professions" in Canadian Law and Society Association, Papers Presented at the Conference Held June 3-6, 1987, McMaster University, Hamilion (North York: YULL Publications, 1988); W.R. Prest, The Rise of the Barristers: A Social History of the English Bar 1590-1640 (Oxford: Clarendon Press, 1986); W.R. Prest, ed., Lawyers in Early Modern Europe and America (New York: Holmes \& Meier, 1981); W.R. Prest, Inns of Court under Elizabeth I and the Early Stuarts, 1590- 1640 (Totowa, N.J.: Rowman and Littlefield, 1972); D.L. Rhode, "An Adversarial Exchange on Adversarial Ethics: Text, Subtext, and Context" (1991) 41 J. Legal Education 29; D. Sugarman, "A Hatred of Disorder': Legal Science, Liberalism, and Imperialism" in Fitzpatrick, ed., Dangerous Supplements, supra note 58 at 34; D. Sugarman, "Simple Images and Complex Realities: English Lawyers and their Relationship to Business and Politics, 1750-1950" (1993) L. \& Hist. Rev. 292; D. Sugarman, "'The Best Organized and Most Intelligent Trade Union in the Country': The Private and Public Life of the Law Society, 1825-1914" in E. Skordaki, ed., Social Change and the Solicitors' Profession (Oxford: Oxford University Press, 1993); D. Sugarman, "Writing 'Law and Society' Histories" in W.R. Cornish \& G. de N. Clark, Law \& Society in England, 1750-1950 (London: Sweet \& Maxwell, 1989). 
First, scholarly histories of common law legal professions point to the novelty rather than the antiquity of many contemporary professional structures, reflecting, as Eric Hobsbawm would have it, the fact that "'[t]raditions' which appear or claim to be old are often quite recent in origin and sometimes invented."148 Because of the extraordinary reliance placed on appeals to "history" in (Anglo-Canadian) professional apologetics, this simple observation may have far-reaching implications. Far from having existed since time immemorial, each of the hallmarks of modern Canadian legal professionalism, as that concept is now understood by lawyers' governing bodies, is of relatively recent origin: monopoly, education, disciplinary powers, codes of ethics. What is more, the modern web of professionalism did not even emerge "naturally" from the irresistible though pure urges of colonial lawyers in British North America to emulate an Imperial model. It is rather the product of their deliberate attempt to create a new professionalism peculiarly suited to the needs of a twentieth century North American state and heavily influenced from south of the border. ${ }^{149}$ Leaders of the British legal professions all opposed the development of a professional ethical code when Winnipeg lawyers spearheaded that initiative in $1919 .{ }^{150}$ The Law Society of England and Wales has never had the sorts of powers that Canadian law societies now take for granted ${ }^{\text {s1 }}$ while the English bar, regardless of what the Law Society of Upper Canada may have said in 1833 or in 1979, did not even begin to develop into a disciplinary institution until the mid-nineteenth century! ${ }^{152}$

A second point which emerges from the scholarly literature is that the legal profession has not always been as single-minded and pure of heart in the pursuit of the public interest as the law societies across Canada would have us believe. Very powerful arguments have been made to the effect that lawyers have used their professional organizations first and foremost to advance their own collective economic interest rather than the public interest at large. ${ }^{153}$ For very many reasons I think this is an unhelpful over-simplification, perhaps even an entirely misleading formulation. ${ }^{154}$ Nonetheless, if one is committed to the workings of the free market (as most of the leaders of

E. Hobsbawm, "Introduction: Inventing Traditions" in E. Hobsbawm \& T. Ranger, eds., The Invention of Tradition (New York: Cambridge University Press, 1983) 1 at 1. For development of these arguments and a review of relevant literatures see Pue, "Becoming Ethical" supra note 82; W.W. Pue, "Common Law Legal Education in Canada's Age of Light, Soap and Water," Canadian Legal History Project Working Paper 93-1 (1993); W.W. Pue, "Lawyers and the Constitution of Political Society: Containing Radicalism and Maintaining Order in Prairie Canada, 1900-1930," Canadian Legal History Project Working Paper 93-4 (1993) (to be published in Karpik \& Halliday, eds., Legal Professions and Political Liberalism, supra note 143). See W.W. Pue, "Becoming Ethical," ibid.

isi R.L. Abel, Legal Profession in England and Wales, supra note 147.

is2 R. Cocks, Foundations of the Modern Bar, supra note 147; "Demons," supra note 82; "Rebels at the Bar," supra note 82; "Moral Panic," supra note 82. See also Abel, ibid.

R.L. Abel, "The Rise of Professionalism," supra note 145; Abel, ibid; R.L. Abel, American Lawyers (New York: Oxford University Press, 1989); H. Arthurs, R. Weisman \& F. Zemans, "Canadian Lawyers, A Peculiar Professionalism" in R. Abel \& P. Lewis, eds., Lawyers in Society: The Common Law World (Berkeley: University of California Press, 1988) 123 at 124, arguing that the Canadian experience generally seems to confirm the "market control" thesis. 
Canadian legal professions would claim to be), the institutions of the legal profession and the histories of many types of interference with free market principles, including freedom of contract, the suppression of economic competitors, restrictions on entry and so on do, to say the least, seem problematic. Certainly, Canadian legal professions have been slow off the mark (generally responding only to great public pressure) to introduce many of the measures of public protection that contemporary law society leaders celebrate. ${ }^{155}$

Thirdly, the history of the organized legal professions in Canada, England and the U.S.A. reveals that lawyers have not always virtuously sought to advance the cause of liberty, democracy and the Canadian way. Professional organizations would be pleased to project the image that they stand somehow apart from politics. They do not. All organizations have their own internal politics - "office" politics, if you will. Moreover, the people who staff and set policy for organizations of all sorts have their own politics, values, opinions. These are not, cannot, be left outside the law society door. The politics which organized legal professions have in fact advanced has not always been liberative. In Canada, it is notorious that the British Columbia law society participated in a McCarthyist suppression of democratic communists after the Second World War, ${ }^{156}$ while Auerbach has documented a pervasive racism, anti-semitism and class bias in the early "American Bar Association."157 The early nineteenth century English bar conspired to preclude the admission of individuals of democratic principle - and were roundly criticized for this in the first Reform Parliament. ${ }^{158}$ In fact, there is no well-documented case of an exercise of disciplinary powers against a barrister by the English Inns of Court during at least the first two-thirds of the nineteenth century, which is entirely free from the taint of political suppression. ${ }^{159}$ Auerbach, Horwitz and Foster have all described an American legal profession captive to large corporate interests. ${ }^{160}$ Backhouse paints a rather unflattering picture of active opposition to equality for women within the Ontario legal profession. ${ }^{161}$ We do not know exactly how or why a code of professional ethics was first developed in Canada but we do know that it emerged from a professional culture which was xenophobic, elitist and

P.G. Giffen, "Social Control and Professional Self-Government: A Study in the Legal Profession in Canada" in S.D. Clark, ed., Urbanism and the Changing Canadian Society (Toronto: University of Toronto Press, 1961) 117.

Martin v. Law Society of British Columbia, [1950] 3 D.L.R. 173 (B.C.C.A.), aff'g [1949] 2 D.L.R. 559; H. Rankin, Rankin's Law: Recollections of a Radical (Vancouver: November House, 1975) at 62 .

J.A. Auerbach, Unequal Justice: Lawyers and Social Change in Modern America, supra note 145. Inns of Court, supra note 140.

See "Demons," supra note 82; "Rebels at the Bar," supra note 82; "Moral Panic," supra note 82; W.W. Pue, "The Benchers' Suppression of an Independent Bar in Victorian England" (Paper presented to Victorian Studies Association of Western Canada Annual Conference, 1992) [unpublished].

J.S. Aurbach, Unequal Justice: Lawyers and Social Change in Modern America, supra note 145; Horwitz, supra note 145; Foster, supra note 145.

Backhouse, supra note 144; C. Backhouse, Petticoats and Prejudice: Women and Law in Nineteenth-Century Canada (Toronto: The Osgoode Society, 1991) at 293, c. 10, "Lawyering: Clara Brett Martin, Canada's First Woman Lawyer." 
generally aligned with capital interests against ordinary citizens. ${ }^{162}$ Far from advancing a liberal notion of advocacy - now all the rage within our governing bodies - the original Canadian Bar Association code of ethics was heavy on duties to "the State" and very light on the theme of vigorous advocacy on behalf of the client. ${ }^{163}$ It is distinctly possible that Canadian lawyers in the early twentieth century developed their profession wholly or partially in order to constrain a democracy which they found frightening. ${ }^{164}$

\section{LAWYER'S HISTORIES: ENGLAND, U.S.A., CANADA — WHO CARES?}

I do not offer these observations as an objective or complete "truth": only as a partial corrective to some of the worst excesses of professional myth as it is propagated in Canada at the present time.

Bridging the gap between historical research and professional rhetoric is essential if we are to develop a perspective on the legal profession, its history and its role in contemporary Canadian society capable of transcending Frye's "cliché and prejudice and stock response." 165 All too often what is presented as "professional" history is merely a melange of assumptions or guesses as to what the history of the legal profession might look like in England or Canada or the U.S.A., far too casually backed up even with reference to existing secondary literatures, much less by credible primary research.

There is some reason for optimism, however. Whatever the failings of comprehension made manifest in their writings, it is encouraging that professional organizations recognize the importance of the history of the legal profession to contemporary practice. Some Canadian legal professions have even acted on this by taking steps to preserve the written records of their history for future generations. The law societies of Ontario, Alberta and British Columbia have established archives programs under the direction of professional archivists. The pool of knowledge and talent represented by Dr. Susan Binnie, Rick Klumpenhower, Bernice Chong and their staffs provides an invaluable resource. The Law Society of Upper Canada has even commissioned a "bicentennial" history to be written by a professional historian. Moreover, every decent Canadian law school now has at least one legal historian on faculty, as do an increasing number of university history faculties. A surprising number of these individuals have worked on the history of the legal profession.

Despite these facts, there are daunting problems to be confronted. The first obstacle lies in bridging the gap which renders the findings of historical research invisible to those who prepare law society reports, documents and submissions. There has been

164 See W.W. Pue, "Lawyers and the Constitution of Political Society: Containing Radicalism and Maintaining Order in Prairie Canada, 1900-1930," supra note 149. 
remarkably little cross-fertilization between history for history's sake and history as professional apologetics.

Moreover, there is a huge amount of basic research yet to be done. The depths of our ignorance are unfathomed. Canada has not yet developed a reasonably complete historical literature on the life and times of even one of its provincial law societies, much less the sorts of synthesis and reflection or prosopography of professional organizations which lies beyond that. More seriously perhaps, we have no credible accounts of the histories of local bar associations and similar professional organizations in the Ottawa Valley, New Westminster, Calgary, Winnipeg, Vancouver, Toronto or elsewhere. Even that peculiarly Canadian engine of twentieth-century professionalization, the Canadian Bar Association, is uncharted historical territory.

We know virtually nothing of the lives of individuals who played obviously crucial roles in Canadian professional formation: James Aikins, H.A. Robson or Chief Justice Mathers of Manitoba; Dr. James Muir of Alberta; Leon Ladner of British Columbia and so on and so on and so on. Even Ontario's William Renwick Riddell is virtual terra incognita despite the ready availability of voluminous published materials and private records. If the "lords" of the profession in times past are almost unknown to us, the ordinary labourers are lost entirely. For most of Canadian history we have no idea whatsoever of where Canadian lawyers have come from, who they were, where they have been trained or how they were socialized.

Similarly, the history of professional ideals, aspirations, ideologies and influences remains to be researched. We have assumed that English influences have been dominant, but have never systematically explored the influences on Canadian legal professionalism from south of the Canadian border or north of the English. ${ }^{166}$ Within Canada, an extremely detrimental assumption has been that the only important developments must have been in Ontario, with the result that the professional histories of the rest of Canada have been almost entirely ignored. The patterns of professional interchange and cross-fertilization of ideas from west to east, from east to centre and between Quebec and the other jurisdictions remains entirely unexplored.

We know far less than we ought to as regards the development of the modern "hallmarks" of professionalism - education, ethics, monopoly - within the Canadian legal profession. We do not know, for example, why a code of professional conduct emerged from prairie Canada in the 1910s nor why it had been resisted in Ontario a decade earlier. We do not know what motivated lawyers to seek self-disciplinary powers in the 1920s or to police so-called "unauthorized practice" in the 1930s, and we have no systematic study of the exercise of professional discipline in Canada over time,

The influences of Scottish law have been left virtually unstudied. A fruitful exploration of Scottish influences on American law is C. Paul Rogers III, "Scots Law in Post-Revolution and NineteenthCentury America: The Neglected Jurisprudence" (1990) 8 Law \& Hist. Rev. 205. DeLloyd Guth has begun an interesting project aimed at reclaiming the history of Scottish influences on Canadian legal structures including the legal profession: D. Guth, "Canada's Four Legal Inheritances" in W.W. Pue \& D. Guth, eds., Canada's Legal Inheritances (Winnipeg: Legal Research Institute and University of Manitoba Press, 1995) [forthcoming]. 
or of other ways in which the "ideal" lawyer has been constructed in various periods. ${ }^{167}$ Though better studied, we still know far less about the history of legal education in Canada than we ought to.

Despite an increasing recognition of the importance of learning more about what lawyers actually do when they are working as lawyers, ${ }^{168}$ the mundane world of legal practice has been left virtually unexplored by Canadian legal historians. We have very little idea of the clients served or interests advanced by Canadian lawyers at any period in the past. ${ }^{169}$ We simply have no idea which specifically "legal" tasks lawyers have performed for their clients or how the range or quality of services provided by lawyers in any given place and time was different from similar services provided by "nonprofessional" competitors.

The tasks before us, then, are enormous. Unfortunately, they are compounded by obstacles of all sorts. Important historical records are destroyed daily across Canada or, more benevolently, simply left to rot. Few of Canada's professional bodies have developed archives programs and each of those in existence could profit from much more generous financial support. Climate-controlled, secure deposit sites for legal history materials are rare. A portion of Manitoba's crucially important legal history, for example, is housed in a small private archive maintained by the volunteer labour of one or two individuals and in space provided by the Faculty of Law. Far from providing an ideal temperature-controlled environment, the stacks are located underneath heating pipes in a basement area which is subject to flooding when the Red River runs high and yet there is at least something in Manitoba.

The exemplary work of Espeland and Halliday on Chicago lawyers' obituaries is intriguing in this latter respect. It can and should be duplicated in Canada. See: W. Espeland \& T.C. Halliday, "Death Becomes Them: Commemoration, Biography and the Ritual Reconstruction of Professional Identity Among Chicago Lawyers in the Late Nineteenth Century" (Paper presented to U.S.A. Law and Society Association Conference, 1994).

So too, the work Dr. Schollenberg has done on the history of professional discipline of physicians in Manitoba is suggestive of work that should be undertaken with respect to the various legal professions across Canada. See E. Schollenberg, The Discipline of Doctors in Manitoba: $A$ Historical and Comparative Perspective (LL.M. thesis, University of Manitoba, 1992). R. Abel \& P. Lewis, "Putting Law Back into the Sociology of Lawyers" in R. Abel \& P. Lewis, eds., Lawyers in Society: Comparative Theories (Berkeley: University of California Press, 1989) 478.

Dale Brawn's ambitious work-in-progress is a rare attempt to explore the relationship between work done and clients served: D. Brawn, "What Differences Did Lawyers Make? Image and Reality in Manitoba, 1909-1919" (Paper presented to Canadian Association of Law Teachers Annual Conference, 1994).

Several of the contributions to Wilton, ed., supra note 144, shed light on the relationship, in general, between lawyers, clients, and interests. See especially c. 2, G.B. Baker, "Law Practice and Statecraft in Mid-Nineteenth-Century Montreal: The Torrance-Morris Firm, 1848 to 1868," ibid. at 45 ; c. 3, "Dimensions of a Law Practice: Brokerage and Ideology in the Career of George-Etienne Cartier," ibid. at 92; c. 7, G.P. Marchildon, "International Corporate Law from a Maritime Base: The Halifax Firm of Harris, Henry, and Cahan," ibid. at 201; c. 10, H.C. Klassen, "Lawyers, Finance, and Economic Development in Southwestern Alberta, 1884 to 1920," ibid. at 298; c. 11, L.A. Knafla, "Richard 'Bonfire' Bennett: The Legal Practice of a Prairie Corporate Lawyer, 1898 to 1913," ibid. at 320 . Other contributions to this collection are outstanding on the general relation of lawyers to business but relate less directly to issues arising from client service. 
The problem of records and archives management is compounded by the effects of the contemporary economic crisis which afflicts Canadian higher education. Unlike other forms of legal research, legal history work is extremely labour-intensive and often requires travel to remote locations in order to access old and rare documents. There is virtually no funding to be found for legal history research. Canada lacks entirely the structures of research fellowships, graduate scholarships, research centres, university research funding and infrastructure support which sustains advanced research in the U.S.A. In the present economic climate, this problem is becoming worse, not better.

Nor do the universities provide a haven for historical contemplation. Legal historians within history departments still have a long way to go to persuade their colleagues that their work differs from the unfashionable and entirely discredited "institutional" approaches with which legal history was once associated. This is especially difficult in areas such as history of the legal profession where, after all, one is to some degree studying the development of an institution.

Legal history is confronted with even more severe obstacles within the law faculties. Most law graduates are ill-prepared by their undergraduate legal education, professional employment or the truncated experience of graduate studies provided by the LL.M. degree for the multiple challenges of historical research. The self-taught retraining program lawyers must put themselves through is difficult, unpleasant and timeconsuming. It is also, as an encounter with the unknown, frightening. Far easier, more comfortable, and safer is a strategy in the pursuit of appointment, tenure, promotion or consulting fees to summarize doctrinal developments or to operate safely at the level of abstract theory unhindered by the need to touch down in empirical history.

Finally, the experience of researching professional history in Canada has, frankly, been frustrating for some who have tried. My own research has taken me to the historical records of five English legal professions and to law society records in five Canadian provinces. While there are great variations within Canada, this experience has generally been such as to persuade me that the easier and more pleasant task by far is to research the history of the English legal professions. ${ }^{170}$

Canadian law societies could be more "user-friendly." At least one graduate student was denied access to records that were crucial to his research. ${ }^{171}$ In another case, interesting and important records were opened for a preliminary study by one graduate

170 I hope this does not sound unduly critical. At a personal level I have been treated very well indeed by three Canadian professional associations with whom I have worked and cordially received by one other. I will always be grateful to Roy Schaeffer and Susan Binnie at the Law Society of Upper Canada Archives, to Deborah McCawley, Chief Executive Officer of the Manitoba Law Society, to Rick Klumpenhouer of the Alberta Legal Archives, to Bernice Chong, Archivist for the Law Society of British Columbia, and to John Martland, past President of the Law Society of Alberta. 
student researcher ${ }^{172}$ only to be closed thereafter to anyone who might want to follow up or further develop the intriguing issues he had opened.

Some Canadian professional associations still seem bemused by the thought that they might actually be worthy of historical study (on the theory that everything important must have happened somewhere else and longer ago). They are also, perhaps, a tad suspicious of historical researchers who might think otherwise. All too often our professional associations have no policy whatsoever regarding maintenance of records or access protocols. Such policies as do exist fall far too often, as Professor Esau has pointed out, into the "fire or ice" categories: rather than developing sensible access protocols, lawyers are inclined towards extremist policies requiring either the burning of records or putting them permanently "on ice," freezing out historical enquiry entirely. ${ }^{173}$

And yet the task must be undertaken, the obstacles confronted. The history of the legal profession lives, as law society publications from coast to coast reveal, in contemporary apologetics. It is crucially important that we constantly seek to produce better history and, in so doing, better "myth." Paul de Metis firm of Beaudry and McPheeters raises a number of fascinating questions relating to the multiple cleavages of Alberta society at the time (ethnicity, political ideology, language, rural-urban, professional-agrarian, etc.). The author was, of course, unable to explore these in depth in the context of an M.A. thesis on a broader topic. Law Society records on these matters are now closed to researchers under the Law Society of Alberta's "access" protocol. 